\title{
Sub-seafloor epidosite alteration: Timing, depth and stratigraphic distribution in the Semail Ophiolite, Oman
}

\author{
Samuel Gilgen ${ }^{\mathrm{a}}$, Larryn W. Diamond ${ }^{* \mathrm{a}}$, Ivan Mercolli ${ }^{\mathrm{a}}$ \\ * Corresponding author: diamond@geo.unibe.ch \\ ${ }^{a}$ Water-Rock Interaction, Institute of Geological Sciences, University of Bern, Balterzstrasse 3, CH-3012 \\ Bern, Switzerland
}

Author contacts:

S. Gilgen: Institute of Geological Sciences, University of Bern, Balterzstrasse 3, CH-3012 Bern, Switzerland Tel. +41316313881

E-Mail: samgilgen@swissonline.ch

L.W. Diamond:

Institute of Geological Sciences, University of Bern, Balterzstrasse 3, CH-3012

Bern, Switzerland

Tel. +41316313881

E-Mail: diamond@geo.unibe.ch

I. Mercolli:

Institute of Geological Sciences, University of Bern, Balterzstrasse 3, CH-3012

Bern, Switzerland

Tel. +41316313881

E-Mail: mercolli@geo.unibe.ch 


\begin{abstract}
Pervasive epidotization of igneous rocks is a common feature in the ophiolite record of hydrothermally altered oceanic crust. Current genetic models view epidosites as markers of focussed upflow of hydrothermal fluid beneath oceanic spreading ridges. The epidosites are envisaged to form at the base of the sheeted dike complex (SDC) during active plate spreading. Our mapping of the Semail ophiolite in Oman has revealed abundant epidosites in the volcanic sequence, some exceeding $1 \mathrm{~km}^{2}$ in extent. They are more frequent and far larger than the mineralogically identical epidosites in the SDC. We have also found epidosites that traverse the entire SDC from bottom to top. Thus, rather than being restricted to the base of the SDC, as implied by current models, epidosites in fact occur throughout the SDC and dominantly within the overlying volcanic pile. We report the occurrence of 19 epidosite bodies and their crosscutting relations with respect to host lava units, dikes, intrusive stocks and also seafloor umbers. The volcanostratigraphic affiliation of the dikes is identified by their whole-rock and clinopyroxene compositions. The relations set constraints on the timing of epidotization with respect to igneous activity in the ophiolite. At least one of the epidosites in the SDC formed during Lasail offaxis volcanism. Another epidosite in the SDC and many in the volcanic units formed later during postspreading, Alley and Boninitic Alley supra-subduction zone volcanism. Only permissive, not compelling, evidence allows just two of the epidosites to have formed within the main-stage SDC during or shortly after its emplacement. We conclude that epidotization of the oceanic crust is not necessarily coupled to spreading ridges and that it can occur during fore-arc volcanism. This finding is consistent with evidence from the modern seafloor and it requires a different hydrothermal environment to that traditionally associated with alteration beneath spreading axes. The timing and stratigraphic constraints show that some of the epidosites formed within the top $1.4 \mathrm{~km}$ of the crust, others between 1.2 and $1.7 \mathrm{~km}$ depth, whereas the deepest formed between 2.6 and $3.8 \mathrm{~km}$ below the paleo-seafloor. Finally, the timing constraints do not prescribe a strict temporal relationship between epidotization and the formation of the numerous seafloor massive-sulphide (VMS) deposits known in the ophiolite. However, a role for epidosites as source rocks for the metals in the deposits remains permissible.
\end{abstract}




\section{Introduction}

Epidosites are metasomatic rocks composed of epidote and quartz with accessory titanite and often magnetite or hematite. They form in various geological settings, most notably in sub-seafloor hydrothermal systems where large quantities of chemically modified seawater react with and replace the basalts, gabbros and rarer plagiogranites that make up the oceanic crust (Seyfried et al., 1988). Hence, epidosites are thought to represent deep segments of major fluid upflow zones in vertically extensive hydrothermal convection cells under active submarine spreading ridges (Richardson et al., 1987; Alt, 1995) or in other submarine extensional structures (e.g. calderas; Galley, 1993). The ascending hydrothermal fluid eventually vents on the seafloor, forming black-smoker-type volcanogenic massive sulphide (VMS) deposits (e.g. Rona, 1988). Epidosites are reported to be depleted in $\mathrm{Cu}$ and $\mathrm{Zn}$ and therefore they are considered to be the source rocks of these metals in the associated VMS deposits (Richardson et al. 1987; cf. Jowitt et al., 2012). Understanding the role of epidosites in sub-seafloor water-rock interaction is thus important for a variety of reasons. Nevertheless, as explained in the following, some basic geological aspects of epidosite formation remain unclear.

Conceptual models of water-rock interaction beneath fast spreading ridges (e.g. Fig. 1) envisage epidotization occurring at the transition between the gabbro and sheeted-dike crustal layers or entirely within the lower portion of the sheeted dike complex (e.g. Richardson et al., 1987; Alt, 1995; Juteau et al., 2000). The models are based on observations in ophiolites around the world (Gillis and Banerjee, 2000): Troodos in Cyprus (Richardson et al., 1987; Schiffman et al., 1985; 1987; Jowitt et al., 2012; Cann et al., 2014), Pindos (Valsami and Cann, 1992), Semail in Oman (Nehlig et al., 1994; Juteau et al., 2000), Josephine in California-Oregon (Harper et al., 1988; Harper, 1995), Karmøy in Norway (Pederson and Malpas, 1994) and Del Puerto in California (Evarts and Schiffman, 1983). According to Banerjee et al. (2000), the only true epidosites sampled to date from the modern seafloor are also hosted by sheeted dikes as well as by tonalite-trondhjemite intrusions, although they were found in a fore-arc zone.

Despite the emphasis in the literature on sheeted dikes as the prime setting of epidosites, several ophiolites are reported to host epidosites in their upper extrusive layers: Pindos (Valsami and Cann, 1992) and Othris in Greece (Valsami et al., 1994), Josephine (Harper, 1995), Solund-Stavfjord in Norway (Fonneland-Jorgensen et al., 2005) and Miaowan in China (Wang et al., 2012). Epidosites also occur in tonalite-trondhjemite stocks that intrude the extrusive rocks (e.g. in Oman; Stakes and Taylor, 2003). Our recent fieldwork in the northern Semail ophiolite has revealed numerous localities with large, spectacular epidosites within the extrusive sequence (pillowed and massive lava flows), as well as in tonalite-trondhjemite and associated gabbro stocks that intrude the volcanic rocks. These occurrences are far more numerous and far larger than those in the underlying Sheeted Dike Complex (SDC). However, as is the case for lava-hosted epidosites in the other ophiolites cited above, the new 
occurrences do not fit the genetic model shown in Fig. 1 and therefore their genesis and significance for sub-seafloor water-rock interaction and for the generation of VMS deposits remain unexplained.

In this paper we take a step towards clarifying these issues by addressing the timing of epidotization relative to major events that punctuate the evolution of the Semail crust: oceanic spreading, plutonism, supra-subduction zone volcanism, crustal-scale faulting and obduction. The results serve to constrain the geological and tectonic setting of the epidotization process as well as providing a means to estimate the depth below seafloor at which epidotization occurred.

Herein we present 11 recently discovered epidosite occurrences in the Fizh and Aswad blocks of the northern Semail ophiolite and we describe their crosscutting relations with respect to various host lava units, dikes, seafloor umbers and intrusive stocks. In addition to occurrences in the extrusive rocks, we report on two new epidosite alteration zones found in the SDC and we include in our discussion the five epidosites previously known in the SDC and related Late Tonalites (Nehlig et al., 1994; Juteau et al., 2000). Existing regional maps of the extrusive rocks in the northern ophiolite do not have the required spatial resolution to assign the discovered epidosites to their exact volcanostratigraphic positions. We therefore present detailed maps and new geochemical analyses (electron microprobe data on igneous clinopyroxenes and whole-rock trace-element concentrations) of the host rocks and crosscutting dikes associated with the epidosites, in order to identify their volcanostratigraphic affiliation with reference to known lava geochemical patterns. This treatment allows the timing of epidotization to be identified precisely at some localities or to be broadly constrained at others, yielding a robust framework in which the geological setting of epidosite genesis is discussed.

\section{Regional geology and alteration patterns of the northern Semail ophiolite}

The Semail ophiolite is an obducted slab of oceanic lithosphere with relatively minor structural complications (Nicolas et al., 2000). Figure 2 shows a geological map of the northern region of Oman adjoining the United Arab Emirates (UAE), where the layering of the oceanic rocks dips 10$40^{\circ}$ to the east. This regional dip exposes an oblique section through the oceanic lithosphere from mantle rocks in the west through to the youngest volcanic rocks in the east. The monotonic, eastwardyounging pattern in the extrusive sequence is locally disrupted by repetitions along low-angle thrusts due to obduction and to exhumation-related block-faulting. However, many of the major steep faults indicated in Fig. 2 are seafloor structures (Reuber, 1988).

The lower crustal sequence in the ophiolite is rather heterogeneous and consists of cumulatelayered gabbros, cumulate planar-laminated gabbros and isotropic "High-Level" gabbros (G) and minor tonalite-trondhjemites (T). These are in turn intruded by "Late Intrusives", including wehrlite, clinopyroxenite and dunite bodies. In contrast to these late ultramafics, "Late Intrusive" gabbro (G') and trondhjemite $\left(\mathrm{T}^{\prime}\right)$ stocks intrude the lower extrusive sequence. The SDC overlies the axial gabbro 
sequence, with an average stratigraphic thickness of about $1500 \mathrm{~m}$ in the northern part of the ophiolite (Lippard et al., 1986).

The extrusive sequence is dominated by basalt to basaltic-andesitic pillowed and massive flows and it can be sub-divided into three to five different units, depending on the literature source (e.g. Alabaster et al., 1982; Ernewein et al., 1988; Gilgen et al., 2014; Kusano et al., 2012; Kusano et al., 2014). Published geological maps use the following threefold volcanostratigraphy with various alternative labels: (1) Geotimes or V1 or SE1; (2) Lasail/Alley/Boninitic Alley or V2 or SE2; (3) Salahi or V3 or SE3. In the area of Fig. 2, Geotimes has been traditionally mapped as a separate unit whereas Lasail/Alley/Boninitic Alley have been lumped together (light pink in Fig. 2) because they are difficult to distinguish reliably using field criteria alone. The Salahi Unit is not present in the area covered by Fig. 2. In this study we use the volcanostratigraphy established by Gilgen et al. (2014), which is based on that by Alabaster et al. (1982) and Kusano et al. (2012), as shown in Fig. 3. The lowermost extrusive unit, the Geotimes, is present all over the Semail ophiolite and has an approximate stratigraphic thickness of $750 \mathrm{~m}$ to $1500 \mathrm{~m}$ (Alabaster et al., 1982). The Geotimes pillows and massive flows represent the axial lavas erupted during concurrent formation of the SDC. Synchronously with the latest Geotimes lavas, the Lasail lavas extruded from local off-axis volcanic centres. These lavas vary in stratigraphic thickness between $0 \mathrm{~m}$ and $750 \mathrm{~m}$ (Alabaster et al., 1982) and they are occasionally interfingered with Geotimes lavas at their base (Kusano et al., 2012; Gilgen et al., 2014). The overlying Alley pillows and massive flows are up to $970 \mathrm{~m}$ in total thickness (Alabaster et al., 1982; Kusano et al., 2014). In contrast, the spatial extent of the Boninitic Alley lavas is not well known. Kusano et al. (2014) demonstrated a thickness of only $140 \mathrm{~m}$ in the Wadi Bidi area (southern Fizh block) but the rather common occurrence of these lavas as hosts of regionally distributed VMS deposits (Gilgen et al., 2014) suggests the unit may be significantly thicker in other areas. The mildly alkaline Salahi Unit, which occurs in only a very restricted geographical area, was emplaced during obduction (Lippard et al., 1986) and it is not considered further in this study.

All the extrusive units have been subjected to sub-seafloor hydrothermal-metamorphic alteration. The general consensus is that the grade of the metamorphic assemblages increases with stratigraphic depth (Lippard et al., 1986, and references therein). The lowest grade metamorphic assemblages include $\mathrm{K}$-rich illite and $\mathrm{Mg}$-rich smectite replacing volcanic glass. Igneous calcic plagioclase is mostly preserved under these conditions. Only Boninitic Alley and, to a minor extent, Alley lavas show such low-temperature assemblages. Most Alley lavas underwent slightly highergrade metamorphism characterized by zeolites and celadonite. In contrast, Lasail lavas more commonly show prehnite \pm epidote alteration. Hematite and accessory epidote and prehnite are characteristic alteration minerals in the Geotimes lavas. In addition to these index minerals, chlorite + albite \pm quartz are omnipresent in all Alley, Lasail and Geotimes lavas.

The surface along which the ophiolite was obducted onto the Arabian continent is marked by a low-angle thrust. Obduction is thought to have begun only a few million years after extrusion of the 
latest lavas (3-7 Ma according to Lanphere, 1981 and Searle et al., 1980; 1-2 Ma according to Hacker et al., 1996 and Rioux et al., 2013). Obduction induced widespread sub-orthogonal sets of normal and strike-slip faults and it segmented the ophiolite into ten major massifs or blocks, which underwent variable amounts of differential rotation (Nicolas et al., 2000). Due to lithostatic rebound of the Arabian continent during obduction in Campanian times, the ophiolite was warped into a regionalscale anticline (Lippard et al., 1986). The area in Fig. 2 lies on the eastern limb of this anticline, hence the $10-40^{\circ}$ dip of the volcanic units towards the NE-SE sector.

\subsection{Timing and tectonic setting and of submarine volcanism}

Various stages of intrusions have been dated in the Semail ophiolite but virtually no datable igneous minerals have been found in the mafic volcanic rocks. Likewise, no datable minerals have been found so far in the epidosites. Unravelling the history of processes leading to formation of the oceanic crust has therefore had to rely on field observations and crosscutting relationships with respect to the dated intrusions. The timing of events relevant to epidosite genesis is shown schematically in Fig. 4a,b. Figure 4d shows the permissible age ranges of the epidosites, as derived in this study and as discussed in following sections.

Radiometric dating of High-Level gabbro and trondhjemite-tonalite intrusions suggests that axial spreading-ridge magmatism had formed the oceanic crust, including the Geotimes lavas, by 95.5 Ma (Tilton et al., 1981; Rollinson, 2009; Rioux et al., 2012, 2013). This age likely coincides with Lasail off-axis volcanism, which began towards the end of Geotimes volcanism (Rollinson, 2009). The spreading ridge could have been situated in an intra-oceanic setting (e.g. Ishikawa et al., 2005) or in a nascent fore-arc above a subducting plate undergoing roll-back (e.g. Whattam and Stern, 2011). After this first phase of volcanism, a hiatus is marked by $0.5 \mathrm{~m}$ to $2 \mathrm{~m}$ thick umbers (Lippard et al., 1986; Kusano et al., 2014). The second phase of volcanism is evidenced by the extrusion of Alley and Boninitic Alley lavas and by the presence of gabbro and tonalite Late Intrusions. Geochronological data on the Late Intrusions in Oman suggest this second phase of volcanism initiated at $\sim 95.2 \mathrm{Ma}$ (Warren et al., 2005; Rioux et al., 2013) in a supra-subduction zone setting (Rollinson, 2009; Kusano et al., 2014). Farther to the north in UAE, the second phase may have begun as early as $96.7 \mathrm{Ma}$ (Goodenough et al., 2010); these ages are disregarded in Fig. 4b. Boninitic Alley lavas extruded generally later than the Alley lavas (Gilgen et al., 2014) but locally synchronously with the latest Alley lavas (Kusano et al., 2014). A $0.5 \mathrm{~m}$ thick umber layer, grading into $6 \mathrm{~m}$ thick pelagic sediments, covers the Boninitic Alley lavas in Wadi Bidi (Kusano et al., 2014). This indicates a major time break until the eruption of the Salahi volcanic rocks in the more southern blocks of the ophiolite (not in the study area).

\section{Previously known epidosites in the Sheeted Dike Complex}


Prior to the present study, three epidosites were known to be hosted by the SDC (Fig. 3a; Juteau et al., 2000; Nehlig et al., 1994). Juteau et al. (2000) report two generations of sheeted dikes that are epidotized in the Muwahyla section of Wadi Hawqayn within the Haylayn Block (Daris area). There, almost $90 \%$ of the epidotized dikes belong to the later generation striking $135^{\circ}-150^{\circ}$, which crosscut the less frequent, earlier dikes striking $10^{\circ}-15^{\circ}$ (Juteau et al., 2000, Reuber et al., 1991). Beurrier et al. (1989) showed that the later sheeted dikes have flat chondrite-normalized REE patterns, as do the earlier Geotimes dikes, but the later generation are comparatively depleted in trace elements. Clearly, the epidotization post-dates the emplacement of the second sheeted dike swarm. Apart from this, no other field relations have been published that constrain the timing of this or the other two epidosites (Wadi Andam in the Samail Block and Salahi in the Salahi Block; Juteau et al. 2000) that are situated entirely within the SDC.

In addition to the above occurrences, two minor epidosites, Hajmilayah and Falah (both in the Haylayn Block; Juteau et al., 2000) occur as fracture-controlled and spotty alterations of High-Level tonalites (marked $\mathrm{T}$ at the base of Fig. 3a) emplaced at the boundary between the SDC and the underlying cumulate gabbros. Accordingly, these epidosites must be younger than the $\sim 97$ Ma onset of this family of intrusions (Fig. 4).

Since the work of Nehlig (1994) these occurrences have been cited as examples of epidosite formation during active axial spreading (e.g. Bird and Spieler, 2004, Cann et al., 2014), in line with the classic model shown in Fig. 1.

\section{Approach and assumptions}

Figure 5 summarizes the 5-step approach taken in this study to determine the timing of pervasive epidotization relative to igneous events in the ophiolite. Step-I entailed deciphering the cross-cutting relations at each epidosite locality (Fig. 5a). Any dike that crosscuts an epidosite body without itself displaying pervasive epidotization was deemed to post-date the epidotization event (e.g. dike 5 in Fig. 5a). This principle relies on the assumption that the non-epidotized dikes were permeable enough to have been epidotized pervasively, had they been present during influx of the Carich fluids that formed the epidosites. This assumption is credible, because all the late dikes in fact display pervasive chlorite-albite alteration, which proves they were permeable to hydrothermal solutions (see event 5 in Fig. 5b).

Care was taken to distinguish pervasive epidotization of the precursor rocks from cases where the rocks contain only veinlets or fracture-coatings of epidote without accompanying selvages of pervasive epidotization. Such veinlets, which are widespread in the ophiolite, often crosscut even the latest dikes (e.g. feature no. 6 in Fig. 5a) and for reasons given in the Discussion, they are not considered to be direct products of the extreme, pervasive metasomatism that formed the epidosites. 
Since field criteria (Gilgen et al., 2014) do not always allow the volcanostratigraphic affiliation of the various lava and dike generations to be identified, samples were taken in this study for geochemical analysis. Building on the work of Alabaster et al. (1982), Ishikawa et al. (2002) and Kusano et al. (2012, 2014), Gilgen et al. (2014) determined that the compositions of relict clinopyroxenes are the most reliable discriminators for the Oman basalts altered to chlorite-albitequartz-hematite assemblages. Where clinopyroxenes are completely altered, Gilgen et al. (2014) found that bulk-rock contents of vanadium and titanium are the most useful amongst the "immobile" trace elements measureable by XRF (immobility of V and Ti during chlorite-albite-quartz-epidotetype alteration has been demonstrated by Humphris and Thompson, 1978 and Pearce and Norry, 1979). Gilgen et al. (2014) found that ratios of other immobile trace-elements suffer from greater overlap between the three volcanostratigraphic units and hence no other discrimination diagrams are presented herein, although complete analyses are provided for reference.

In contrast to the regionally prevalent chlorite-albite-quartz alteration of the basalts, we found that pervasive epidotisation not only destroys igneous clinopyroxenes, but it markedly changes vanadium contents. This finding precludes analysing the epidosites themselves to determine the volcanostratigraphic affinity of their precursor rocks. Therefore in Step-II, rock samples with as little epidote as possible were collected at each epidosite locality for geochemical analysis (blue squares in Fig. 5a).

After performing the geochemical analyses in step-III, sufficient information was available to assign each lava and dike in the cross-cutting sequence to a volcanostratigraphic unit (step-IV). This in turn allowed in step- $\mathrm{V}$ upper and lower limits to be placed on the possible age of epidosite formation within the context of the dated igneous events shown in Fig. 4.

\section{Methods}

\subsection{Outcrop mapping and sampling}

Reconnaissance fieldwork was conducted over swaths of the volcanic sequence and the SDC. The larger of the discovered epidosites were mapped on GPS-referenced digital tablets at scales varying from 1:2,500 to 1:25,000, using published 1:50,000 geological maps as a basis (BME, 1987; BRGM 1993a, 1993b).

\subsection{Whole-rock and mineral geochemistry}

The whole-rock elemental compositions of host-rock lavas were determined using a PANalytical $^{\mathrm{TM}}$ Axios wavelength-dispersive X-ray fluorescence (XRF) instrument with a rhodium source tube at voltages of 20 to $60 \mathrm{kV}$ and beam current of 40 to $100 \mathrm{~mA}$. Besides the major oxides 
$\mathrm{SiO}_{2}, \mathrm{TiO}_{2}, \mathrm{Al}_{2} \mathrm{O}_{3}, \mathrm{Fe}_{2} \mathrm{O}_{3}, \mathrm{MnO}, \mathrm{MgO}, \mathrm{CaO}, \mathrm{Na}_{2} \mathrm{O}, \mathrm{K}_{2} \mathrm{O}$, and $\mathrm{P}_{2} \mathrm{O}_{5}$, the trace elements Rb, $\mathrm{Ba}, \mathrm{Sr}, \mathrm{Nb}$, $\mathrm{Zr}, \mathrm{Hf}, \mathrm{Y}, \mathrm{Ga}, \mathrm{Zn}, \mathrm{Cu}, \mathrm{Ni}, \mathrm{Co}, \mathrm{Cr}, \mathrm{V}, \mathrm{Sc}, \mathrm{La}, \mathrm{Ce}, \mathrm{Nd}, \mathrm{Pb}$, Th, and $\mathrm{U}$ were measured in 1:5 dilithium tetraborate (Spectromelt ${ }^{\circledR}$, Merck) diluted fused beads. Weight loss on ignition (LOI) was determined by heating the milled rock powder for exactly $2 \mathrm{~h}$ at $1,050{ }^{\circ} \mathrm{C}$.

Polished thin-sections of the samples were examined petrographically and the compositions of relict igneous clinopyroxene crystals were measured using a Jeol ${ }^{\mathrm{TM}}$ JXA-8200 electron microprobe with a beam voltage of $20 \mathrm{kV}$ and a beam current of $15 \mathrm{nA}$. The major elements $\mathrm{Si}, \mathrm{Mg}, \mathrm{Ca}$, and $\mathrm{Fe}$ were measured, as well as the trace elements $\mathrm{Al}, \mathrm{Na}, \mathrm{Ti}, \mathrm{Cr}$, and $\mathrm{Ni}$. Median $\mathrm{Ti}$ contents and corresponding $\mathrm{Mg} /(\mathrm{Mg}+\mathrm{Fe})$ ratios (reported as $\mathrm{Mg \# )}$ as well as core-to-rim trends were determined according to the procedure in Gilgen et al. (2014).

\section{Results}

\subsection{Regional distribution of epidosites}

Our reconnaissance mapping within the Fizh and Aswad blocks of the northern Semail ophiolite showed that epidosites are common and quite regularly distributed along the volcanic sequence (Fig. 2). The epidosites vary in outcrop size from $<10 \mathrm{~m}^{2}$ (bordering sets of brittle faults) to $>1 \mathrm{~km}^{2}$ (pervasive alteration mostly of porous pillow lavas). The selected occurrences shown in Fig. 2 all have areas larger than $10,000 \mathrm{~m}^{2}$, the largest being Ajeeb with $>0.6 \mathrm{~km}^{2}$ (no. 4 in Fig. 2). Included in these areas are large zones of pure epidosite (described below) plus surrounding zones in which > $60 \mathrm{vol} . \%$ of the outcrop consists of epidote + quartz.

\subsection{Petrography}

Figure 6 shows representative microscope images of the hydrothermally altered precursor lavas and dikes and of their epidotized equivalents. The most common rocks affected by epidotization are dark Geotimes lavas. Their fine- to medium-grained volcanic textures are well preserved, including spherical vesicles and pseudomorphs of phenocrysts. However, apart from relict clinopyroxenes, their igneous mineralogy has been completely replaced by fine-grained chlorite + albite + quartz \pm prehnite \pm pumpellyite + accessories (titanite + hematite/maghemite + calcite) (Fig. 6a,b). Geotimes dikes show analogous but coarser-grained textures (Fig. 6e).

Rocks completely altered to epidosite have lost the igneous textures and dark grey colour of their precursors and instead are yellowish-green and macroscopically equigranular, similar to porous sandstones in appearance. They consist of $\sim 40-45$ vol. $\%$ epidote $+45-40$ vol. $\%$ quartz +2 vol. $\%$ titanite +1 vol. $\%$ hematite and over 10 vol.\% pore space (Fig. 6c,d,f). Epidote and quartz occur as relatively coarse, short prismatic crystals (50-400 $\mu \mathrm{m}$ length), mostly with euhedral outlines. The pores are thus true intercrystalline vugs, rimmed by euhedral crystal faces (Fig. 6f). Titanite and 
hematite occur as clouds of tiny specks, entirely enclosed by both epidote and quartz (Fig. 6c,d,f). Rocks that are only partially epidotized contain relict chlorite and little or no albite.

\subsection{Assignment of sampled lavas and dikes to volcanostratigraphic units}

Before describing the timing relations at each epidosite occurrence, the sampled epidote-poor pillow lavas, massive flow lavas and dikes are first assigned to volcanostratigraphic units according to their geochemical characteristics. Tables 1 and 2 list the whole-rock and clinopyroxene compositions of the samples. The core-to rim zonation of $\mathrm{Mg \#}$ and $\mathrm{Ti}$ contents within clinopyroxenes in 23 samples is plotted in Fig. 7a and the whole-rock Ti and V concentrations in 31 samples are plotted in Fig. 7b, colour-coded according to the unit to which the samples have been assigned. Eight of the samples in Fig. $7 \mathrm{~b}$ do not appear in Figs. 7a because they contain no relict clinopyroxenes (cf. Tables 1 and 2). The coloured fields in Fig. 7 define the compositional ranges of the four relevant volcanostratigraphic units based on several hundred analyses in the literature (Alabaster et al. 1982; Ishikawa et al., 2002; Kusano et al., 2012, 2014; Gilgen et al., 2014). Also shown in Fig. 7b are grey sectors corresponding to tectonic settings of basalt volcanism according to Shervais (1980). The arrow labelled "epidotization" shows an example of vanadium loss associated with pervasive epidotization, which disqualifies epidosites as discriminators of volcanostratigraphic units (see section 4).

The unnumbered symbols in Fig. 7 correspond to samples for which the volcanostratigraphic unit implied by the coloured fields in Fig. 7a agrees with that in Fig. 7b. These include pillow lavas that display field characteristics compatible with the assigned units according to the criteria in Gilgen et al. (2014). The numbered symbols in Fig. 7 refer to samples whose volcanostratigraphic identity is less straightforward. They plot within overlapping regions of adjacent unit fields, or they plot within different unit fields in Figs. 7a and 7b. However, these complications are readily resolved, as follows.

Samples RN2 and RN5 come from the same pillow lava horizon at the Wadi Rajmi epidosite. Their clinopyroxenes both indicate Lasail but the V content of RN2 plots above the shaded Lasail unit in Fig. 7b. Likewise, dike 15-16 from the Rusays South epidosite contains typical Lasail clinopyroxenes but elevated whole-rock V. Pillow lava WF6 also contains Lasail-type clinopyroxenes but its $\mathrm{V}$ content falls below the shaded Lasail field in Fig. 7b. There is no reason to doubt the V analyses in these three cases, so we have expanded the Lasail V-Ti field in Fig. 7b as indicated by the tan-coloured dashed line.

Pillow sample 13-61 from the Ajeeb epidosite contains no clinopyroxene and in Fig. 7b it falls within the overlap between the Lasail and Geotimes units. However, field criteria clearly distinguish it as a Lasail lava. Clinopyroxenes in Ajeeb dike 14-48 plot in the overlap between Alley and Lasail in Fig. 7a, but the V content of the sample lies below $270 \mu \mathrm{g} / \mathrm{g}$ in Fig. $7 \mathrm{~b}$, thereby indicating Lasail affinity. Accordingly we have slightly expanded the Lasail field in Fig. 7a as indicated by the dashed curve. 
Dike samples 14-35A and 14-50 from Ajeeb contain Boninitic Alley clinopyroxenes, distinguished by variable $\mathrm{Mg \#}$ at uniformly low Ti. Their boninitic character is supported by low $\mathrm{Na}_{2} \mathrm{O}$ contents, in accord with data in Kusano et al. (2012) and Gilgen et al. (2014). As these samples overlap slightly with the Lasail field in Fig. 7b we have enlarged the Boninitic Alley field as indicated by the dark-brown dashed curve.

\subsection{Volcanostratigraphic positions and timing of lava-hosted epidosites}

The following sections describe the observations used to place the various epidosite occurrences into the volcanostratigraphic framework of Gilgen et al. (2014). The results are summarized in Fig. 3b, including schematic sketches of the known cross-cutting relations at each site. Figure $4 \mathrm{~d}$ shows for each epidosite the feasible age span (green bars) that is consistent with the deduced cross-cutting relations. Within the time span indicated by each green bar, the epidotization event may have been short-lived or protracted and it may have been continuous or episodic.

\subsubsection{The Ajeeb epidosite}

The Ajeeb epidosite is the largest coherent body found so far within the extrusive sequence and it exhibits numerous crosscutting features that constrain the timing of its formation. The main (eastern) part of the epidosite was mapped for this study at 1:2,500 scale (Fig. 8). The assignment of volcanostratigraphic units shown in Fig. 8 is based on the geochemical results in Gilgen et al. (2014) and in section 6.3 (see also Tables 1 and 2). The epidotization affects a series of Geotimes and interfingered Lasail pillow basalts and subordinate Geotimes massive flows that dip 10-25 ${ }^{\circ} \mathrm{NE}$ to SE. The pits of three mined-out VMS deposits (Hatta Main, Hatta Extended and Hatta South) are located to the east of the main epidosite zone. An umber of 10-50 cm thickness marks the paleo-seafloor horizon on which the massive sulfides were deposited. The three deposits overlie Geotimes pillow lavas and they are capped by a Geotimes massive flow. Obduction-related normal faults downthrow some sections of the sequence in the west of the area and thereby repeat in outcrop the massive flow that caps the VMS deposits in the east of the area.

Epidosites make up $44 \%$ of the mapped area of volcanic rocks at Ajeeb (Fig. 8). Epidotization affects dominantly the Geotimes lavas (Fig. 9a,b) and also small volumes of the interfingering Lasail pillow lavas. In Figs. 8 and 9c it can be seen that the massive flow overlying the Hatta VMS bodies is also pervasively epidotized at certain sites. Only patchy epidotization occurred in the immediate footwall of the deposits. Another important observation is the ubiquitous presence of pervasive epidotization of the umbers that mark the VMS seafloor horizon (Fig. 9d).

Numerous sub-vertical feeder dikes of Geotimes, Alley and Boninitic Alley affinity run E-W across the intensely epidotized central zone of the mapped area (Fig. 8). Within this zone the Geotimes dikes always contain pervasive epidotization as patches or bands parallel to the dike walls (Fig. 10a). 
The fine-grained, narrower Alley dikes show clear epidotization along chilled margins or as patches of pervasive epidosite within the dike cores (Fig. 10b). Strikingly, none of the three identified Boninitic Alley dikes show any signs of epidotization, even though their immediately adjacent host-rocks are intensely epidotized (Fig. 10c). These three dikes do not have well developed chilled margins and they are generally fine-grained, indistinguishable from unaltered Alley dikes. The Boninitic Alley dikes exhibit partial albitization of igneous plagioclase and pervasive chlorite alteration, the latter also affecting the margins of the epidotized wall rocks (e.g. Fig. 10c).

Overall, the above cross-cutting relations demonstrate that epidotization at Ajeeb began after at least some Alley dikes had intruded and it ended prior to intrusion of the Boninitic Alley dikes. A green bar indicating these timing brackets is shown in Fig. $4 \mathrm{~d}$.

\subsubsection{Other lava-hosted epidosites}

The volcanostratigraphic positions of the other lava-hosted epidosite localities in Fig. $3 b$ have been deduced from the Aswad, Fizh and Wadi Bani Umar 1:50,000 geological maps (BME, 1987; BRGM, 1993a, 1993b), from our own field observations and from the geochemical analyses in section 6.3 and Tables 1 and 2, as explained in the following.

The Haduf East epidosite, which lies just north of Ajeeb, and the Rusays and Bani Umar South epidosites are stratigraphically located at the contact of Geotimes to Lasail lavas (Fig. 3b). The large pillow size, the reddish-brown colour of the pillows and the absence of large phenocrysts confirm that the lower lavas hosting these epidosites belong to the Geotimes Unit, as the BRGM mapping suggests and as corroborated by analyses of samples 14-21 and WF8. The upper epidotized lavas appear on the BRGM maps as V2 (i.e. Lasail, Alley or Boninitic Alley) but our geochemical analyses of samples 1408, 14-20 and WF6 show they belong to the Lasail Unit at each of the three epidosite localities.

The epidosites at Haduf West, Shiyya, Raast al-Milh, Rusays South and Wadi Rajmi each occur entirely within a single volcanic unit (Fig. 3b). Haduf West lies stratigraphically beneath the Haduf East epidosite, i.e. at the base of the Geotimes Unit and only $250 \mathrm{~m}$ from the underlying SDC. The Shiyya epidosite lies stratigraphically beneath the Rusays epidosite north of Wadi Fizh and hence it is hosted by the Geotimes Unit. According to the published geological map it sits in the middle of this unit. The Rusays South epidosite is located slightly higher up in the Geotimes lavas. It hosts an epidotized Lasail dike (sample 15-16). Thus, the Rusays South epidosite must postdate early Lasail volcanism (Fig. 4d). Analysis of samples RaM10, RN2 and RN5 reveal that the Raast al-Milh and Wadi Rajmi epidosites sit within Lasail pillow lavas. The Wadi Rajmi epidosite is situated approximately $100 \mathrm{~m}$ above the contact to the underlying Geotimes Unit whereas Raast al-Milh lies some $450 \mathrm{~m}$ above the contact. It therefore occupies the highest stratigraphic position of all the epidosites investigated in this study (Fig. 3b). 
The Saruj, Bani Umar North and Jiltah epidosites are interesting because they crosscut Late Intrusive bodies. The Saruj epidosite is situated chiefly within Geotimes pillow lavas which are readily identifiable based on field criteria. The epidosite is described by Stakes and Taylor (1992) as being part of a hydrothermal alteration halo above the Aarja-Bayda tonalite intrusion ("plagiogranite" in Stakes and Taylor, 1992). In contrast to their observation, we found that the epidosite (Fig. 11a) mainly occurs on the SW margin of the tonalite and therefore it sits stratigraphically beside the intrusion rather than above it. Additionally, we found that smaller-scale epidosite alteration is present on the northern contact between the tonalite and the Geotimes pillow lavas. Moreover, significant epidosite alteration is present along and beside joint sets within the intrusion itself (Fig. 11b). This indicates that the epidotization occurred after the Aarja-Bayda tonalite had cooled into the brittle regime. Similarly, the Bani Umar North epidosite is located primarily within Geotimes pillow lavas (BME, 1987) adjacent to a late tonalite-gabbro intrusive body. However, as in the preceding case, epidotization evidently postdates the intrusion, as evidenced by locally pervasive alteration in the gabbro section of the intrusive complex (Fig. 11c). The third example of an epidosite in close vicinity of a Late Intrusive body is the Jiltah alteration zone. The small tonalite body is cut by epidote + quartz veinlets but it also shows locally pervasive, patchy to spotty epidosite alteration (Fig. 11d). The Jiltah epidosite extends into the surrounding Geotimes lavas, as demonstrated by analysis of sample 16-4584.

\subsection{Newly discovered epidosites in the Sheeted Dike Complex}

Two new occurrences of significant epidosite alteration have been found in the Fizh block. The Fazah epidosite is located approximately in the centre of the SDC in the eastern part of Wadi Fizh (No. 11, Fig. 2). The alteration here affects large areas of sheeted dikes and a Late Intrusive gabbrotonalite complex (Fig. 12a). Several generations of Alley dikes within the gabbro body are epidotized (dike C in Fig. 12b; sample 15-09), but the latest dike of all, which belongs to Boninitic Alley is not epidotized (dike 3 in Fig. 12c; sample 15-06). Whole-rock geochemistry (Table 1) show that some of the epidotized dikes are of Alley affinity whereas the unaltered late dike belongs to Boninitic Alley (Fig. 12d). Thus, the epidotization is deduced to have occurred during late Alley or early Boninitic Alley volcanism.

The second new epidosite within the SDC, Rajmi West, occurs along a rather narrow belt of outcrops, extending more or less continuously over $950 \mathrm{~m}$ of stratigraphic height from the base of the SDC into the lowermost of the overlying pillow lavas. This long epidotized zone also crosscuts HighLevel tonalite intrusions, but it is itself crosscut by two late Boninitic Alley dikes (samples TB02, TB05), which show no epidotization (Fig. 3b). These relations show that epidotization could have occurred at any time between Lasail and late Alley volcanism (Fig. 4d).

6.6 New information on previously known epidosites in the Sheeted Dike Complex 
The Hawqayn epidosite (Fig. 13) was reported by Juteau et al. (2000) to be situated at the base of the SDC (Fig. 3a). However, our field mapping shows that it lies well above the base, only about $250 \mathrm{~m}$ from the top of the SDC (compare position in Fig. 3b). We also discovered an unaltered dike that crosscuts the Hawqayn epidosite (Fig. 12). Geochemical analysis (Tables 1 and 2) shows that it is of Lasail affinity. Accordingly, the Hawqayn epidosite must have formed at some time between solidification of the second stage of sheeted dikes and late Lasail volcanism. Rioux et al. (2013) radiometrically dated the first stage of sheeted dikes at $\sim 96 \mathrm{Ma}$ and the second at $\sim 95.5 \mathrm{Ma}$. Figure $4 \mathrm{~d}$ thus allows for only a very restricted time interval $(\sim 0.2 \mathrm{Ma})$ in which the Hawqayn epidosite could have formed.

\subsection{Depth of epidotization below paleo-seafloor}

Knowledge of the age span and stratigraphic positions of the epidosites allows limits to be placed on their depths of formation below the paleo-seafloor. As an example of how the depth ranges are calculated, we consider the Raast Al-Milh epidosite, which sits in the middle of the Lasail Unit the highest stratigraphic position of all the studied epidosites (Fig. 3b). The epidosite could have formed at the earliest during mid-Lasail time (Fig. 4d), in which case it would have been emplaced just below the paleo-seafloor. The latest it could have formed is at the end of pre-obduction volcanism in the ophiolite (Fig. 4d), when its current stratigraphic site was buried under the top half of the Lasail Unit plus possibly the entire thickness of the overlying Alley/Boninitic Alley lavas, i.e. $1350 \mathrm{~m}$ in total. Thus, the upper age limit implies a shallow emplacement ( $\sim \mathrm{m}$ depth at $\sim 95.6 \mathrm{Ma}$ ) whereas the lower age limit implies deep emplacement ( $\sim 1350 \mathrm{~m}$ at $\sim 94 \mathrm{Ma}$ ). Assuming a constant rate of accumulation of the volcanic pile, the resulting permissible age-depth range is depicted in Fig. 14 as a straight line with a positive slope.

Table 3 lists the permissible depth ranges estimated in this way, based on the local beddingorthogonal thicknesses of unfaulted volcanic units at each epidosite locality (rather than using the generalized thicknesses shown in Fig. 3b), and taking into account the vertical thickness of the epidosite bodies themselves. Besides Raast al-Milh, Fig. 14 shows permissible depth ranges for the four other epidosites that have the tightest age constraints and hence the tightest depth constraints, as explained in the following.

The age of the Ajeeb epidosite is bracketed between early and late Alley volcanism. Ajeeb lies near the top of the Geotimes, overlain by Lasail and a thick pile of Alley lavas. Approximately the centre of the Alley pile is marked by the Shinas VMS deposit (Gilgen et al., 2014), which is located $4.5 \mathrm{~km}$ ESE from the easternmost Ajeeb outcrops. Using a conservative dip of $10^{\circ} \mathrm{E}$ for the volcanic sequence, this distance implies $780 \mathrm{~m}$ of volcanic overburden above Ajeeb if it formed in late Alley time. The maximum depth can be estimated from the maximum conceivable overburden during early Alley time. This corresponds to the sum of the maximum thickness of Lasail (750 m; Alabaster et al., 
1982) plus the maximum thickness of Alley (970 m; Kusano et al., 2014). Therefore, the Ajeeb epidosite is constrained to have formed somewhere in the range of 780 to $1700 \mathrm{~m}$ below the paleoseafloor.

The Hawqayn epidosite formed after the second stage of sheeted dikes in the Hayalyn Block and before termination of Lasail volcanism. Its minimum depth of formation is therefore set by its stratigraphic depth below the SDC/Geotimes boundary $(250 \mathrm{~m})$ plus the thickness of overlying Geotimes lavas (1000 m). Its maximum depth is set by adding $500 \mathrm{~m}$ of Lasail overburden. Thus, the Hawqayn epidosite must have formed between 1250 and $~ 1750 \mathrm{~m}$ below the paleo-seafloor.

The epidotization at Fazah occurred between early Alley volcanism and the beginning of Boninitic Alley volcanism. Its minimum depth of formation is therefore defined by the thickness of overlying SDC at this locality $(1200 \mathrm{~m})$, plus the entire Geotimes $(1000 \mathrm{~m})$, the thinnest feasible cover of Lasail $(250 \mathrm{~m})$ and the lower third of Alley lavas at this particular site $(145 \mathrm{~m})$. The maximum is defined by taking the thickest feasible cover of Lasail $(750 \mathrm{~m})$ plus $820 \mathrm{~m}$ of Alley below a $150 \mathrm{~m}$ cap of Boninitic Alley. Thus, the epidosite formed between 2600 and $3770 \mathrm{~m}$ below the paleo-seafloor.

\section{Discussion}

\subsection{Coherency of epidosite characteristics}

All the 19 pervasive epidosites examined in this study, whether hosted by the pillow lavas, by the SDC or by intrusive bodies, are petrographically and mineralogically identical, regardless of their stratigraphic position. All these epidosites can therefore be viewed as a coherent phenomenon. Their uniform mineralogy suggests formation temperatures in the range $\sim 250-400{ }^{\circ} \mathrm{C}$ (Bird and Spieler, 2004), without any systematic indications of temperature dependency on volcanostratigraphic position. Although the epidosites within the SDC contain small amounts of amphibole, these are relicts from the earlier regional diabase alteration (clinopyroxene + Ca-plagioclase + albite + actinolite + sphene \pm chlorite \pm epidote), rather than belonging to the epidosite paragenesis itself (Nehlig et al., 1994).

\subsection{Significance of late epidote veinlets}

As shown in Fig. 5 (event 6), epidote veinlets and fracture coatings, often accompanied by quartz but always without selvages of pervasive epidotization, often cross-cut all other outcrop features. Because of their relative timing and their wide distribution, we do not consider them to be direct products of the hydrothermal alteration that formed the massive, pervasive epidosite bodies. In areas of massive epidosites these veinlets are attributed to ingress of minor quantities of late pore fluids that equilibrated with the pre-existing epidosite and then reprecipitated epidote \pm quartz in nearby fracture porosity. 


\subsection{Outcrop evidence for timing of epidotization in the Sheeted Dike Complex}

Nehlig (1991) emphasized that epidotization in the SDC is usually limited to individual dikes and that it does not crosscut the dike margins. Figure 13a illustrates epidotization at the Hawqayn locality that is at some places restricted to individual dikes (area 1) but at others it crosscuts adjacent dikes (area 2). Nehlig (1991) suggested that the pattern of epidotization arose from fluid-rock reactions occurring in each dike individually, shortly after its emplacement and solidification. Cann et al. (2014) reached the same conclusion for epidotized dikes in the Troodos ophiolite, Cyprus. The prime evidence there is that dikes which are completely epidotized crosscut some dikes with only patchy epidotization.

While we view the dike-by-dike alteration mechanism of Nehlig (1991) and Cann et al. (2014) as plausible, our field observations in both the SDC and the volcanic sequence in the Semail ophiolite have led us to another, at least equally plausible, explanation for these outcrop features. The permeability of individual dikes is clearly highly heterogeneous, a fact acknowledged by Cann et al. (2014). Thus, epidotization varies from patchy (e.g. Fig. 10b), with coarser-grained dike cores being more strongly epidotized than chilled margins, through to complete alteration. The degree of alteration may change strongly along the length of individual dikes (e.g. Fig. 13a) and adjacent dikes may have very different permeabilities at their contacts, the later dike being more permeable than the earlier dike or vice versa. Likewise, the permeability of pillow lavas is highly non-uniform. For example, at intermediate intensities of epidotization in the Geotimes Unit, the interpillow hyaloclastites and the pillow cores are entirely epidotized but the less permeable pillow rims remain unaffected by the epidotizing fluid (Fig. 10d). Since paleo-flow directions are generally oblique to outcrop surfaces, the observations in both the SDC and the pillow lavas can, in our opinion, be explained if the epidotizing fluid passed through a pre-existing, heterogeneous permeability network in one alteration event per locality, without the need to invoke sequential (e.g. dike-by-dike) alteration. This alternative interpretation opens the possibility that the epidotization occurred well after the host SDC had been emplaced. For example, where the epidosite at Fazah alters the SDC, it is indistinguishable from all the other epidosites in the SDC. However, part of same epidosite overprints a nearby Late Gabbro (Fig. 12), proving that the alteration occurred in late Alley time at least $1 \mathrm{Ma}$ after the SDC had solidified (see short age-bar for Fazah in Fig. 4d). For the sites where such clear crosscutting features are absent, long age-bars have drawn in Fig. $4 \mathrm{~d}$ to express the long span of permissible formation ages of the epidosites hosted by the SDC.

\subsection{Constraints on the geological and tectonic setting of epidotization}


The volcanostratigraphic positions and age-spans of the epidosites inferred above (Figs. 3b and 4) collectively impose constraints on any geological models that can be proposed to explain the epidotization. In the following we discuss three models in the light of these new data.

(1) Syn-spreading model. The long-established model summarized in Fig. 1 envisages epidosites forming during active sub-seafloor spreading (Richardson et al., 1987; Alt, 1995; Cann et al., 2014). A hot axial gabbroic magma chamber drives deep convection of seawater into a hightemperature reaction zone where the fluid acquires a Ca-enriched, $\mathrm{Mg}$-depleted composition appropriate to stabilize epidosite at lower temperatures. Focussed ascent of this fluid causes epidotization of the base of the SDC. However, even for the Troodos ophiolite there has been some discussion as to whether epidotization was syn-spreading or not. Schiffman et al. (1987) deduced a post-spreading, off-axis setting for the Troodos epidosites, based on the crosscutting trend of the altered zone compared to the orientation of the SDC. In contrast, Varga et al. (1999) argued using paleomagnetic measurements that the epidotization indeed predated extensional rotation of the SDC during advanced spreading. Their approach is founded on the assumption that the contemporary magnetic field is recorded by the new mineral assemblage formed during epidotization, rather than simply being inherited in magnetically unreset, relict Fe-Ti-oxides. We are not aware if this assumption has been tested.

The syn-spreading model was reinforced by the studies of Nehlig et al. (1994) and Juteau (2000) on the five epidosite occurrences at the base of the SDC in the Semail ophiolite (Fig. 3a). These authors concluded that the epidosites formed soon after solidification of the dike complex. Whereas this timing is plausible for the Wadi Andam, Salahi and Hawqayn occurrences, it is not the only timing possibility (see section 7.3 and Fig. 4), and it cannot apply to the epidosites in the SDC at Hajmiliyah and Falah, because they crosscut High Level tonalites (Fig. 3b). Moreover, the model in Fig. 1 is unable to account for the abundant post-spreading epidosites situated within the volcanic sequence of the ophiolite.

(2) Intrusion-related model. Galley (1993) emphasized that epidosites can form in a variety of submarine extensional settings (e.g. calderas), not just at spreading axes. His model involves the same essential components as the syn-spreading model, but the magma bodies driving seawater convection may be any members of the gabbro-tonalite-trondhjemite suite as long as they are linked to extensional faults that focus ascent of the chemically evolved fluid. Epidosites form at the base of the up-flow zone, altering the overlying country rocks of the intrusion and also the intrusion itself.

This model can explain many of the features summarized in Figs. 3b and 4. The Wadi Andam, Salahi and Hawqayn epidosites may be permissibly ascribed to axial magmatic activity as part of the main and late spreading stages, respectively (i.e. in line with the syn-spreading model); the Hajmiliyah and Falah epidosites can be attributed to intrusion of the High Level 
Tonalites at the base of the SDC (labelled T in Fig. 3b), whereas the younger epidosites at Saruj, Bani Umar North and Jiltah can be ascribed to Late Intrusives (gabbros G' or tonalites T' in Fig. 3b). Although the Fazah epidosite sits in part within a Late Intrusive, its alteration of a postintrusive Alley dike suggests it formed somewhat later. However, the 9 epidosites in the volcanic sequence, including the largest occurrences of all, remain without any known nearby intrusive body to which their formation can be attributed. Table 4 shows that the nearest outcropping intrusives at stratigraphically deeper levels are too far (up to $5 \mathrm{~km}$; distances uncorrected for the regional $10-40^{\circ} \mathrm{E}-\mathrm{SE}$ regional dip of the volcanic sequence) to be drivers of high-flux hydrothermal convection. There is always the possibility that the responsible intrusions lie hidden at depth or have been already eroded, but it seems remarkable that none of the large epidosites shows any sign of a related intrusion, even though some of them (e.g. Ajeeb, Haduf West, Haduf East) are exposed over stratigraphic intervals of up to $600 \mathrm{~m}$. In some cases, e.g. northern Wadi Fizh, intrusions may have been removed by obduction-related block faulting. On the other hand, huge amounts of High Level and Late Intrusives crop out in the northern ophiolite, including in the Alley Unit (Fig. 2), but with no associated epidosites. Therefore, although the intrusion-related model is consistent with the timing and stratigraphic depth of half of the investigated epidosites in Oman, there is no positive evidence to link intrusions to the other half of the (mostly larger) epidosites.

(3) Crustal-fault-related model: Another conceivable way to repeatedly form epidosites through time is to circulate seawater through crustal-scale oceanic faults that are intermittently reactivated, flow being driven by regional-scale, thermal-hydraulic gradients rather than by local-scale gradients such as those surrounding individual High Level or Late Intrusive bodies. The geological map of the northern Semail ophiolite in Fig. 2 shows several major faults, some of which can be traced into the mantle peridotite. Reuber (1988) recognized hydrothermal alteration of these large-scale shear zones in the Fizh and southern Aswad blocks and suggested they facilitated deep penetration of seawater. The Ajeeb, Raast al-Milh, Wadi Rajmi, Bani Umar North and Bani Umar South epidosites are all located close to major fault zones that can be traced into lower crustal levels (Fig. 2). Most of these structures are interpreted to have formed synchronously with the Late Intrusives, as indicated by syn-tectonic intrusion of wehrlites at Wadi Fayd (Reuber, 1988), close to the Raast al-Milh epidosite. Similarly, MacLeod and Rothery (1992) described mafic intrusions associated with the Wadi Hatta shear zone, adjacent to which the Ajeeb epidosite is located. This prominent fault zone is widely accepted to be the segmentation zone of a spreading ridge and thus it had large vertical as well as lateral extent during sub-seafloor igneous activity (Nicolas et al., 2000). The five mentioned epidosites do not sit within the large-scale fault structures themselves but could perhaps be interpreted to be fed by related second- or third-order faults. 
Overall, however, only a few of the epidosites so far appear to be convincingly associated with crustal-scale faults. In Fig. 2 it can be seen that the well-exposed crustal section in the northern Wadi Fizh area is remarkably intact, undissected by major fault zones. Here the Rusays and Shiyya epidosites sit within the lower and middle part of the volcanic pile. These are thus examples of intense epidotization without any obvious links to major structural breaks. On the other hand, the boundaries of the massifs may themselves have once been major subseafloor fault zones prior to dismemberment of the ophiolite during obduction. If this were the case, then the horizontal component of fluid flow from these structures to the sites of pervasive epidotization would have to have been in the order of several kilometres to explain the observations. The feasibility of the crustal-fault-related model is therefore unclear based on the observations at hand.

\subsection{Link between epidosites and plate subduction}

By about $95 \mathrm{Ma}$, some $2 \mathrm{Ma}$ after cessation of the axial spreading, the Semail ophiolite was situated above a subduction-zone, either a shallowly subducting oceanic plate in an intra-oceanic setting (e.g. Ishikawa et al., 2005) or in a nascent fore-arc setting (e.g. Whattam and Stern, 2011). As mentioned in the Introduction, it is an intriguing fact that the only welldocumented epidosites recovered from the modern seafloor have been dredged from the Tongan fore-arc (i.e. from the trench wall of the overriding plate; Banerjee et al., 2000). Deep-sea drilling into the in-situ crust has so far failed to intersect epidosites (Staudigel, 2014). In a review of hydrothermal alteration in ophiolites, Gillis and Banerjee (2000) underscored the apparent lack of epidosites in modern mid-ocean ridge (MOR) environments and suggested that epidosites in general may be restricted to supra-subduction-zone settings. The epidosites in the supra-subduction-zone Ilvisaartoq greenstone belt in West Greenland (Polat et al., 2007) may be another example of this pattern in the Mesoarchean. So far, however, no reasons for this apparent correlation with tectonic setting have been proposed and it therefore remains simply empirical. Geochemical investigations of epidosites have not documented input of fluid derived specifically from subduction-zones or their magmas, whereas evidence for seawater modified by interaction with oceanic crust is compelling. Nevertheless, the fact that almost all the studied epidosites in the Semail ophiolite could permissibly have formed in the supra subduction-zone setting is suggestive.

\section{Conclusions}

Current models of hydrothermal alteration in the layered oceanic crust emphasize the restricted stratigraphic position and timing of pervasive epidosite bodies. Based largely on work in the Troodos 
ophiolite, epidotization is considered to occur at the base of the SDC immediately after or even during dike emplacement, i.e. during active plate spreading (Schiffman et al., 1987; Richardson et al., 1987; Nehlig et al., 1994; Alt, 1995; Juteau et al., 2000; Cann et al., 2014). Our new evidence from the world's largest ophiolite shows that these conceptual restrictions on position and timing of epidotization in the oceanic crust need to be lifted.

The SDC in the Semail ophiolite is exposed over an outcrop area of approximately $1,400 \mathrm{~km}^{2}$ but only five rather small epidosites have been found in it previously and only two more have been discovered in the present work. Among these seven occurrences, two occur within the top third of the SDC and one traverses the entire SDC from its base into the capping lavas. Moreover, this study has revealed that the Geotimes and Lasail Units of the volcanic sequence, which are exposed over a far smaller area of approximately $250 \mathrm{~km}^{2}$, contain abundant epidosite bodies up to $1 \mathrm{~km}^{2}$ in extent. These bodies are mineralogically and texturally identical to those in the SDC. Thus, rather than being restricted to the base of the sheeted-dike layers, epidosites in fact occur throughout the SDC and dominantly within the overlying volcanic pile.

Regarding timing of the seven epidosites in the Semail SDC, five of the occurrences exhibit cross-cutting relations with respect to late dikes and High Level Trondhjemites. In each case these relations prove that epidotization occurred after the main axial spreading event that generated the SDC. Four of these epidosites could have formed at the earliest during off-axis Lasail volcanism, whereas in the fifth case (Fazah), epidotization is tightly constrained to the first half of Alley fore-arc volcanism. Only the two remaining epidosites (Wadi Andam and Salahi), which by chance exhibit no field relations with respect to intrusions or late dikes, could permissibly have formed during injection or soon after solidification of the SDC, as suggested by current models in the literature. However, these two epidosites could just as well have formed at any later, post-spreading time prior to obduction.

The timing results for the twelve epidosites in the lavas are similar to those in the SDC. Wherever crosscutting relations are observed, they prove that the epidosites post-date the main stage of spreading and indeed many of the epidosites must have formed during post-ridge Alley volcanism. Whereas previous studies in the Troodos ophiolite assign all the epidotization to the oceanic-spreading setting, there is no compelling evidence for this in the Semail ophiolite. Therefore, the current models of hydrothermal alteration of the oceanic crust must be extended to allow for major events of postspreading epidotization.

For 16 of the studied localities, broad constraints have been set on the possible depth below the paleo-seafloor at which epidotization occurred. The results allow epidotization of the SDC anywhere between 1.3 and $3.8 \mathrm{~km}$ depth, whereas epidotization of the volcanic rocks could have occurred anywhere between 0 and $2.5 \mathrm{~km}$ depth. Very shallow epidotization is permissible at seven localities and indeed Harper et al. (1988) showed in the Josephine ophiolite (California) that epidotization can occur as close as $75 \mathrm{~m}$ below the seafloor. 
A cursory comparison of Figs. $4 \mathrm{c}$ and $4 \mathrm{~d}$ suggests that epidotization could have been coeval with the formation of the 18 main seafloor VMS deposits known in the Semail ophiolite. In detail, however, none of the epidosites with tight age constraints overlaps in time with the oldest group of 11 VMS deposits, which formed just below or on top of the Geotimes lavas during axial spreading or early off-axis Lasail volcanism (Gilgen et al., 2014). Nevertheless, seven epidosites with loose age constraints overlap with this group. A second group of seven VMS deposits formed during postspreading Alley and Boninitic Alley volcanism (Gilgen et al., 2014). All but one of the 19 studied epidosites could have been coeval with this second group. The only exception is the Hawqayn epidosite, which formed in late Lasail time during the $~ 1$ Ma gap between the two generations of VMS deposits. In conclusion, the available evidence does not prescribe a strict temporal link between epidotization and VMS deposits but it also does not rule out the proposed role of epidosites as source rocks for metals in VMS deposits (Richardson et al. 1987; cf. Jowitt et al., 2012).

This study has demonstrated that epidotization of the oceanic crust is not necessarily coupled to spreading ridges and that it can be active during supra-subduction zone volcanism in the fore-arc setting. This finding, which is consistent with the scant evidence from the modern seafloor (Banerjee et al., 2000), requires a different hydrothermal environment to that traditionally associated with subseafloor alteration beneath spreading axes. Whereas Late Intrusives or large-scale faults could arguably have driven or localized the requisite water flux for epidotization of the Semail ophiolite, such features are not present near all the investigated sites and therefore no satisfactory model for the nature and mechanism of hydrothermal circulation can be proposed at present. Further research into the characteristics of sub-seafloor hydrothermal activity above subduction zones may illuminate this issue.

\section{Acknowledgements}

Tom Belgrano, Alannah Brett, Nevena Novakovic, Fabian Scherer, Yves Vogt and Lea Weyermann kindly assisted with field mapping. We are most grateful to Khalid Al-Tobi and Mohammed AlSuleimani (Earth Secrets Co., Oman) for logistical help. We appreciate the support of Mr. Salim Omar Al-Ibraheem (DG) and Mohammed Al-Battashi at the Directorate General of Minerals, Sultanate of Oman. We thank Martin Robyr for assistance with microprobe analyses, and Peter Ulmer and Lydia Zehnder for help with XRF analyses at ETH Zurich. Constructive comments on this manuscript by Paola Tartarotti, Marco Scambelluri and an anonymous journal reviewer helped clarify the presentation. We acknowledge funding by Swiss National Science Foundation SNSF Grant 200021146211 to L.W. Diamond. 


\section{References}

Alabaster, T., Pearce, J.A., Malpas, J., 1982. The volcanic stratigraphy and petrogenesis of the Oman ophiolite complex. Contributions to Mineralogy and Petrology 81 (3), 168-183.

Alt, J.C., 1995. Sub-seafloor Processes in Mid-Ocean Ridge Hydrothermal Systems, Seafloor Hydrothermal Systems: Physical, Chemical, Biological, and Geological Interactions. In: Humphris, S.E., Zierenberg, R.A., Mullineaux, L.S., Thomson, R.E., (Eds.), Geophysical Monograph, 91, pp. 85-114.

Banerjee, N.R., Gillis, K.M., Muehlenbachs, K., 2000. Discovery of epidosites in a modern oceanic setting, the Tonga forearc. Geology 28 (2), 151-154.

Beurrier, M., Ohnenstetter, M., Cabanis, B., Lescuyer, J., Tegyey, M., Metour, J., 1989. Géochimie des filons doléritiques et des roches volcaniques ophiolitques de la nappe de Semail : contraintes sur leur origine géotectonique au Crétacé supéerieur. Bull. Soc. géol. France 8, 205-219.

Bird, D.K., Spieler, A.R., 2004. Epidote in geothermal systems. Reviews in Mineralogy and Geochemistry 56 (1), 235-300.

BME (Bishimetal Exploration Co.), 1987. Geological Map of Wadi Bani Umar (Scale 1:50,000: sheet NG40-14E-II): Ministry of Petroleum and Minerals, Sultanate of Oman.

BRGM (Bureau de Recherches Géologique et Minères), 1993a. Geological Map of Aswad (Scale 1:50,000: sheet NG40-14B $\left.\mathrm{B}_{1} / \mathrm{B}_{2}\right)$ : Ministry of Petroleum and Minerals, Sultanate of Oman.

BRGM (Bureau de Recherches Géologique et Minères), 1993b. Geological Map of Fizh (Scale 1:50,000: sheet NG40-14B 4 ): Ministry of Petroleum and Minerals, Sultanate of Oman.

Cann, J.R., McCaig, A.M., Yardley, B.W.D., 2014. Rapid generation of reaction permeability in the roots of black smoker systems, Troodos ophiolite, Cyprus. Geofluids 15, 179-192.

DGM (Directorate General of Minerals), 1992. Geological Map of Buraimi (Scale1:250,000; sheet NG 40-14), Directorate General of Minerals, Ministry of Petroleum and Minerals, Sultanate of Oman.

Ernewein, M., Pflumio, C., Whitechurch, H., 1988. The death of an accretion zone as evidenced by the magmatic history of the Sumail ophiolite (Oman). Tectonophysics 151 (1-4), 247-274.

Evarts, R.C., Schiffman, P., 1983. Submarine hydrothermal metamorphism of the Del Puerto Ophiolite, California. American Journal of Science 283, 289-340. 
Fonneland-Jorgensen, H., Furnes, H., Muehlenbachs, K., Dilek, Y., 2005. Hydrothermal alteration and tectonic evolution of an intermediate- to fast-spreading back-arc oceanic crust: Late Ordovician Solund-Stavfjord ophiolite, Western Norway. Island Arc 14 (4), 517-541.

Galley, A.G., 1993. Characteristics of semi-conformable alteration zones associated with volcanogenic massive sulphide districts. Journal of Geochemical Exploration 48, 175-200.

Gilgen, S.A., Diamond, L.W., Mercolli, I., Al-Tobi, K., Maidment, D.W., Close, R., Al-Towaya, A., 2014. Volcanostratigraphic Controls on the Occurrence of Massive Sulfide Deposits in the Semail Ophiolite, Oman. Economic Geology, 109 (6), 1585-1610.

Gillis, K.M., Banerjee, N.R., 2000. Hydrothermal alteration patterns in supra-subduction zone ophiolites. Geological Society of America Special Papers 349, 283-298.

Goodenough, K.M., Thomas, R.J., Styles, M.T., Schofield, D.I., MacLeod, C.J., 2014. Records of ocean growth and destruction in the Oman-UAE ophiolite. Elements 10 (2), 109-114.

Hacker, B.R., Mosenfelder, J.L., Gnos, E., 1996. Rapid emplacement of the Oman ophiolite: Thermal and geochronologic constraints. Tectonics 15 (6), 1230-1247.

Harper, G.D., Bowman, J.B., Kuhns, R., 1988. A field, chemical, and stable isotope study of subseafloor metamorphism of the Josephine ophiolite. Journal of Geophysical Research 93 $4625-4656$.

Harper, G.D., 1995. Pumpellyosite and prehnitite associated with epidosite in the Josephine ophiolite Ca metasomatism during upwelling of hydrothermal fluids at a spreading axis. Geological Society of America Special Papers 296, 101-122.

Ishikawa, T., Nagaishi, K., Umino, S., 2002. Boninitic volcanism in the Oman ophiolite: Implications for thermal condition during transition from spreading ridge to arc. Geology 30, 899-902.

Ishikawa, T., Fujisawa, S., Nagaishi, K., Masuda, T., 2005. Trace element characteristics of the fluid liberated from amphibolite-facies slab: Inference from the metamorphic sole beneath the Oman ophiolite and implication for boninite genesis. Earth and planetary science letters $240(2), 355-377$.

Jowitt, S.M., Jenkin, G.R.T., Coogan, L.A., Naden, J., 2012. Quantifying the release of base metals from source rocks for volcanogenic massive sulphide deposits: Effects of protolith composition and alteration mineralogy. Journal of Geochemical Exploration 118, 47-59.

Juteau, T., Manac'h, G., Moreau, O., Lecuyer, C., Ramboz, C., 2000. The high temperature reaction zone of the Oman ophiolite: new field data, microthermometry of fluid inclusions, PIXE analyses and oxygen isotopic ratios. Marine Geophysical Researches 21 (3-4), 351-385. 
Kusano, Y., Adachi, Y., Miyashita, S., Umino, S., 2012. Lava accretion system around mid-ocean ridges: Volcanic stratigraphy in the Wadi Fizh area, northern Oman ophiolite. Geochemistry Geophysics Geosystems 13 (5), 1-25.

Kusano, Y., Hayashi, M., Adachi, Y., Umino, S., Miyashita, S., 2014. Evolution of volcanism and magmatism during initial arc stage: constraints on the tectonic setting of the Oman Ophiolite. Geological Society, London, Special Publications 392 (1), 177-193.

Lanphere, M.A., 1981. K-Ar ages of metamorphic rocks at the base of the Samail ophiolite, Oman. Journal of Geophysical Research 86 (B4), 2777-2782.

Lippard, S.J., Shelton, A.W., Gass, I.G., 1986. The ophiolite of northern Oman. Blackwell Scientific Publications Ltd. 165 pp.

MacLeod, C., Rothery, D., 1992. Ridge axial segmentation in the Oman ophiolite: evidence from along-strike variations in the sheeted dyke complex. Geological Society, London, Special Publications 60 (1), 39-63.

Nehlig, P., 1991. Salinity of oceanic hydrothermal fluids: a fluid inclusion study. Earth and Planetary Science Letter 102, 310-325.

Nehlig, P., Juteau, T., Bendel, V. and Cotten, J., 1994. The root zones of oceanic hydrothermal systems - constraints from the Semail ophiolite (Oman). Journal of Geophysical Research: Solid Earth 99 (B3), 4703-4713.

Nicolas, A., Boudier, E., Ildefonse, B., Ball, E., 2000. Accretion of Oman and United Arab Emirates ophiolite - Discussion of a new structural map. Marine Geophysical Researches 21 (3-4), $147-179$.

Polat, A., Appel, P.W.U., Frei, R., Pan, Y., Dilek, Y., Ordóñez-Calderón, J.C., Fryer, B., Hollis, J.A., Raith, J.G., 2007. Field and geochemical characteristics of the Mesoarchean ( 3075 Ma) Ivisaartoq greenstone belt, southern West Greenland: Evidence for seafloor hydrothermal alteration in supra-subduction oceanic crust. Gondwana Research 11, 69-91.

Pedersen, R.B., Malpas, J., 1984. The origin of oceanic plagiogranites from the Karmøy ophiolite, western Norway. Contributions to Mineralogy and Petrology 88 (1-2), 36-52.

Reuber, I., 1988. Complexity of the crustal sequence in the northern Oman ophiolite (Fizh and southern Aswad blocks): the effect of early slicing? Tectonophysics 151 (1), 137-165. 
Reuber, I., Nehlig, P., Juteau, T., 1991. Axial segmentation at a fossil oceanic spreading centre in the Haylayn block (Semail nappe, Oman): off-axis mantle diapir and advancing ridge tip. Journal of Geodynamics 13 (2), 253-278.

Richardson, C.J., Cann, J.R., Richards, H.G., Cowan, J.G., 1987. Metal-depleted root zones of the Troodos ore-forming hydrothermal systems, Cyprus. Earth and Planetary Science Letters, 84 (2-3), 243-253.

Rioux, M., Bowring, S., Kelemen, P., Gordon, S., Dudas, F., Miller, R., 2012. Rapid crustal accretion and magma assimilation in the Oman-UAE ophiolite: High precision U-Pb zircon geochronology of the gabbroic crust. Journal of Geophysical Research-Solid Earth 117, B07201-07212.

Rioux, M., Bowring, S., Kelemen, P., Gordon, S., Miller, R., Dudás, F., 2013. Tectonic development of the Samail ophiolite: High- precision U- Pb zircon geochronology and Sm-Nd isotopic constraints on crustal growth and emplacement. Journal of Geophysical Research: Solid Earth 118 (5), 2085-2101.

Rollinson, H., 2009. New models for the genesis of plagiogranites in the Oman ophiolite. Lithos 112 (3-4), 603-614.

Rona, P.A., 1988. Hydrothermal mineralization at oceanic ridges. Canadian Mineralogist 26, 431-465.

Schiffman, P., Smith, B. M., Varga, R. J., Eddy, C., Moores, E. M., 1985. Low ${ }^{18}$ O epidosites along fossil hydrothermal feeders for massive sulphide deposits, Solea graben, northern Troodos ophiolite (abstract), EOS, Transactions of the American Geophysical Union 66, 402.

Schiffman, P., Smith, B.M., Varga, R.J., Moores, E.M., 1987. Geometry, conditions and timing of offaxis hydrothermal metamorphism and ore-deposition in the Solea graben. Nature 325, $423-425$.

Searle, M.P., Lippard, S.J., Smewing, J.D., Rex, D.C., 1980. Volcanic rocks beneath the Semail Ophiolite nappe in the northern Oman mountains and their significance in the Mesozoic evolution of Tethys. Journal of the Geological Society of London 137 (5), 589-604.

Seyfried, W.E., Berndt, M.E., Seewald, J.S., 1988. Hydrothermal alteration processes at mid-ocean ridges; constraints from diabase alteration experiments, hot spring fluids and composition of the oceanic crust. The Canadian Mineralogist 26 (3), 787-804.

Shervais, J.W., 1980. Ti-V plots and the petrogenesis of modern and ophiolitic lavas. Earth and Planetary Science Letters 59, 101-118. 
Stakes, D.S., Taylor, H.P., 1992. The Northern Samail Ophiolite: An Oxygen Isotope, Microprobe, and Field Study. Journal of Geophysical Research 97 (B5), 7043-7080.

Stakes, D.S., Taylor, H.P., 2003. Oxygen isotope and chemical studies on the origin of large plagiogranite bodies in northern Oman, and their relationship to the overlying massive sulphide deposits. In: Dilek, Y. and Robinson, P.T. (Eds.) Ophiolites in Earth History. Geological Society, London, Special Publications 218, 315-351.

Staudigel, H., 2014. Chemical fluxes from hydrothermal alteration of the oceanic crust, in: Holland, H.D., Turekian, K.K. (Eds.), Treatise on Geochemistry, 2nd Edition. Elsevier, Oxford, pp. 583-606.

Tilton, G.R., Hopson, C.A., Wright, J.E., 1981. Uranium-lead isotopic ages of the Samail ophiolite, Oman, with applications to Tethyan ocean ridge tectonics. Journal of Geophysical Research 86 (B4), 2763-2775.

Valsami, E., Cann, J.R., 1992. Mobility of rare earth elements in zones of intense hydrothermal alteration in the Pindos ophiolite, Greece. In: Parson, L.M. (Ed.), Ophiolites and Their Modern Oceanic Analogues. Geological Society, London, Special Publications 60, 219232.

Valsami, E., Cann, J., Rassios, A., 1994. The mineralogy and geochemistry of a hydrothermal alteration pipe in the Othris ophiolite, Greece. Chemical geology 114 (3), 235-266.

Varga, R.J., Gee, J.S., Bettison-Varga, L., Anderson, R.S., Johnson, C.L., 1999. Early establishment of seafloor hydrothermal systems during structural extension: paleomagnetic evidence from the troodos ophiolite, cyprus. Earth and planetary science letters 171(2), 221-235.

Wang, J., Kusky, T., Polat, A., Wang, L., Peng, S., Jiang, X., Deng, H., Wang, S., 2012. Sea-floor metamorphism recorded in epidosites from the ca. 1.0 Ga Miaowan ophiolite, Huangling anticline, China. Journal of Earth Science 23 (5), 696-704.

Warren, C., Parrish, R., Waters, D., Searle, M., 2005. Dating the geologic history of Oman's Semail ophiolite: insights from U-Pb geochronology. Contributions to Mineralogy and Petrology $150(4), 403-422$.

Whattam, S.A., Stern, R.J., 2011. The `subduction initiation rule': a key for linking ophiolites, intraoceanic forearcs, and subduction initiation. Contributions to Mineralogy and Petrology $162,1031-1045$. 


\section{Figure Captions}

Fig. 1: $\quad$ "Classic" water-rock interaction model for the formation of epidosites under an active oceanic spreading ridge, based on Schiffman et al. (1985), Richardson et al., (1987) and Alt (1995). Epidosites are restricted to the base of the Sheeted Dike Complex.

Fig. 2: Geological map of the Aswad and Fizh blocks in the northern Semail ophiolite, Oman. Redrawn after DGM (1992), with selected structures from Nicolas et al. (2000). Green dots show 14 new occurrences of epidosites identified in this study: 12 in the volcanic sequence (including those in Late Gabbros $\mathrm{G}^{\prime}$ and Tonalites $\mathrm{T}^{\prime}$ ) and 2 the Sheeted Dike Complex (SDC).

Fig. 3: Schematic stratigraphy of the crustal section of the Semail ophiolite (volcanostratigraphy after Gilgen et al., 2014, and references therein) showing positions of epidosites (pistachio-green bodies). High Level Intrusions (tonalites T and gabbros $\mathrm{G}$ ) sit at the base of the sheeted dikes. Late Intrusions (tonalites $\mathrm{T}^{\prime}$ and gabbros $\mathrm{G}^{\prime}$ ) sit in the volcanic units. (a) Epidosites known prior to the present study: three in the Sheeted Dike Complex, two in High Level Gabbros (Hajmiliyah and Falah; Nehlig et al., 1994; Juteau et al., 2000) and one above the Aarja-Bayda intrusion (Stakes and Taylor, 1992). (b) Overlay of previously known epidosites shown in (a) with 14 new occurrences discovered in this study: 12 in the volcanic sequence and 2 in the Sheeted Dike Complex. Feeder dikes at the Fazah, Rajmi West, Hawqayn, Ajeeb and Rusays South epidosites are color-coded to show their affiliation to the Alley or Boninitic Alley volcanic units. The epidosite at Hawqayn is shown at a higher stratigraphic position than in (a).

Fig. 4: Timing constraints on hydrothermal sub-seafloor epidotization. (a) Radiometric ages of igneous bodies. G, T: High Level Gabbro and Tonalite. G', T': Late Gabbro and Tonalite. (b) Summary of igneous activity in the central and northern Semail ophiolite in Oman (excluding UAE data; see text). SDC: Sheeted Dike Complex. (c) Ages of volcanogenic massive sulphide (VMS) deposits. (d) Permissible ages of epidosites (this study). (e) Obduction. See text for literature sources.

Fig. 5: Summary of strategy for sampling and analysis. (a) Illustration of common crosscutting relations at epidosite outcrops. (b) Steps followed in this study to identify the timing of epidotization relative to igneous events at each of the studied epidosite occurrences. Note that fracture-fillings of epidote without wall-rock selvages of epidosite (event 6) do not constitute "epidosite" (see text). 
Fig. 6: Petrographic images of epidosites and their precursor rocks. (a) Pillow basalt of the Geotimes Unit showing the regionally prevalent facies of subseafloor hydrothermal alteration. Microphenocrysts of igneous clinopyroxene $(\mathrm{Cpx})$ are oxidized and former plagioclase laths are altered to albite $(\mathrm{Ab})$. Aggregates of hydrothermal chlorite (Chl) and hematite/maghemite (Ox) sit in a fine matrix $(\mathrm{Mx})$ of quartz + albite. Plane-polarized transmitted light, Sample 040212-5, N40 4420752684402 (b) Sample in (a) viewed in cross-polarized light. (c) Geotimes pillow basalt completely altered to epidosite. Equigranular epidote (Ep) and quartz (Qz) enclose clouds of titanite (Ttn) and hematite (Hm) specks. Plane-polarized transmitted light. Sample LW5-C (Ajeeb), N40 431948 2739735. (d) Sample in (c) viewed in crosspolarized light. (e) Geotimes dike containing relatively fresh igneous clinopyroxene $(\mathrm{Cpx})$ surrounded by albite $(\mathrm{Ab})$ pseudomorphs of plagioclase phenocrysts embedded in a matrix of chlorite (Chl). (f) SEM backscattered electron (BSE) image of a typical epidosite illustrating the interlocking texture of euhedral quartz (Qz) and epidote (Ep) enclosing specks of titanite (Ttn) and hematite (Hem). Intercrystalline pores are true vugs between euhedral crystal faces. Sample SG1443 (Ajeeb), N40 4317472739254.

Fig. 7: Geochemical identification of the volcanostratigraphic affiliation of lavas and dikes at epidosite occurrences. Dots, squares and arrows denote samples analysed in this study (see Tables 1 and 2 for full analyses and distinction between pillowed and massive flows). Only samples whose identification requires discussion are numbered (see text). Large fields represent compositional extents of the four host volcanostratigraphic units in the ophiolite, based on analyses of epidote-poor samples in Alabaster et al. (1982), Kusano et al. (2012) and Gilgen et al. (2014). (a) Core-to-rim zonation trends of electron microprobe analyses of relict igneous clinopyroxene phenocrysts. $\mathrm{Mg} \#=$ molar ratio $\mathrm{Mg} /\left(\mathrm{Mg}+\mathrm{Fe}^{2+}\right)$; $\mathrm{Ti}[\mathrm{apfu}]=$ titanium atoms per formula unit. The start of the arrow marks the median of these clinopyroxenes (as given in Table 2). (b) Whole-rock contents of titanium and vanadium. Grey fields represent tectonic settings after Shervais (1981). The "epidotization" arrow joins the mean of 4 non-epidotized pillow lavas at Ajeeb (labelled "nE") with the mean of 4 epidotized pillow lavas at Ajeeb (labelled "E"), demonstrating that epidotization depletes $\mathrm{V}$ contents.

Fig. 8: Geological map of the eastern portion of the Ajeeb epidosite, showing the distribution of hydrothermal alteration. The bedding of the Geotimes and Lasail lavas dips $10-30^{\circ} \mathrm{NE}-\mathrm{SE}$. The volcanostratigraphic affiliations of the lavas and 
dikes are based on analyses of relict clinopyroxenes and of trace elements in whole-rock samples.

Fig. 9: Outcrop features of lavas and umber at the Ajeeb epidosite. (a) Complete, pervasive epidosite alteration of Geotimes pillow lavas (40N 432203 2739838). (b) Incipient epidosite alteration of Geotimes pillow lavas. Pervasive epidotization is restricted to the interpillow hyaloclastite (40N 432180 2739570). (c) Pervasive epidotization in the massive Geotimes flow overlying the Hatta VMS deposits (cf. Fig. 6) (40N 431888 2739467). (d) Pervasively epidotized umber marking the seafloor horizon on which the Hatta VMS deposits formed (40N 432653 2739443).

Fig. 10: Outcrop features of dikes and pillow lavas at the Ajeeb epidosite. (a) Pervasive epidotization in the centre of a Geotimes dike. Weak epidotization in the margins of the dike has permitted deeper incision and fracturing by surface weathering (40N 432053 2739690). (b) Patchy, pervasive epidotization of an Alley dike (40N 432006 2740003). (c) Epidote-free Boninitic Alley dike crosscutting intensely epidotized Geotimes pillow lavas (40N 432239 2739689). (d) Intermediate epidosite alteration of pillowed Geotimes lava (40N 432059 2739602). White dashed lines indicate pillow boundaries. Interpillow hyaloclastite (ip) and cores of the pillows are highly epidotized, whereas the rims are macroscopically unaltered. This suggests a permeability-controlled alteration process (see text for discussion).

Fig. 11: Outcrop features of epidosites altering Late Intrusives. (a) Intensely epidotized Geotimes Pillow lavas (Saruj epidosite), which constitute the country rocks of the Aarja-Bayda tonalite (40N 438846 2695198). (b) Epidosite alteration of the AarjaBayda Late Tonalite, focussed along brittle fractures (40N 439082 2695360). (c) Pervasive epidosite replacement band and adjacent weak epidote alteration in the Bani Umar North Late Gabbro (40N 438106 2703620). (d) Patchy and spotty epidotization in the Jiltah Late Tonalite (40N 430304 2743758).

Fig. 12: $\quad$ Epidosite alteration within the Sheeted Dike Complex at Fazah (eastern Wadi Fizh area). (a) Simplified geological map showing the extent of the Late Intrusive gabbro (G') and tonalite (T') bodies. Epidosite (Ep) is observed within the Sheeted Dike Complex on the E and NW side of the gabbroic intrusion, within the gabbro itself and within dikes crosscutting the gabbro. Blue and red squares indicate location of crosscutting features in (b) and (c), respectively. (b) Three different generations of dikes (A-C; from early to late) crosscut the Late Intrusive gabbro (G'). All show epidosite alteration, but to distinctly different degrees: dikes A and C show patchy pervasive alteration; dike B only epidosite veinlets (40N 443040 
2710781). (c) Three different generations of dikes (1-3; from early to late) crosscut the Late Intrusive gabbro (G'). Dikes 1 and 2, which contain zones of epidosite, are cross-cut by dike 3, which contains no epidosite (40N 443031 2710820). (d) Whole-rock geochemistry (Table 1) reveals the Alley character of dike $\mathrm{C}$ in Fig. (b) and the Boninitic Alley character of dike 3 in Fig. (c).

Fig. 13: Sheeted Dike Complex at Hawqayn locality. (a) Epidosite alteration (pistachio green) is in some cases confined to individual dikes (e.g. area 1), whereas in others it crosscuts dike boundaries (e.g. area 2). (b) A non-epidotized dike of Lasail affinity (see text) crosscuts epidotized sheeted dikes (40N 2609158 539327). This constrains the age of the epidosite to be after emplacement of the 2nd-stage sheeted dikes and before the end of Lasail volcanism.

Fig. 14: Constraints on depth below the paleo-seafloor at which epidosites formed in the Semail ophiolite. Lines define the range in depths permitted by cross-cutting relationships at the specified localities (see text). Within each line, all depths are equally probable. 
Figure 1

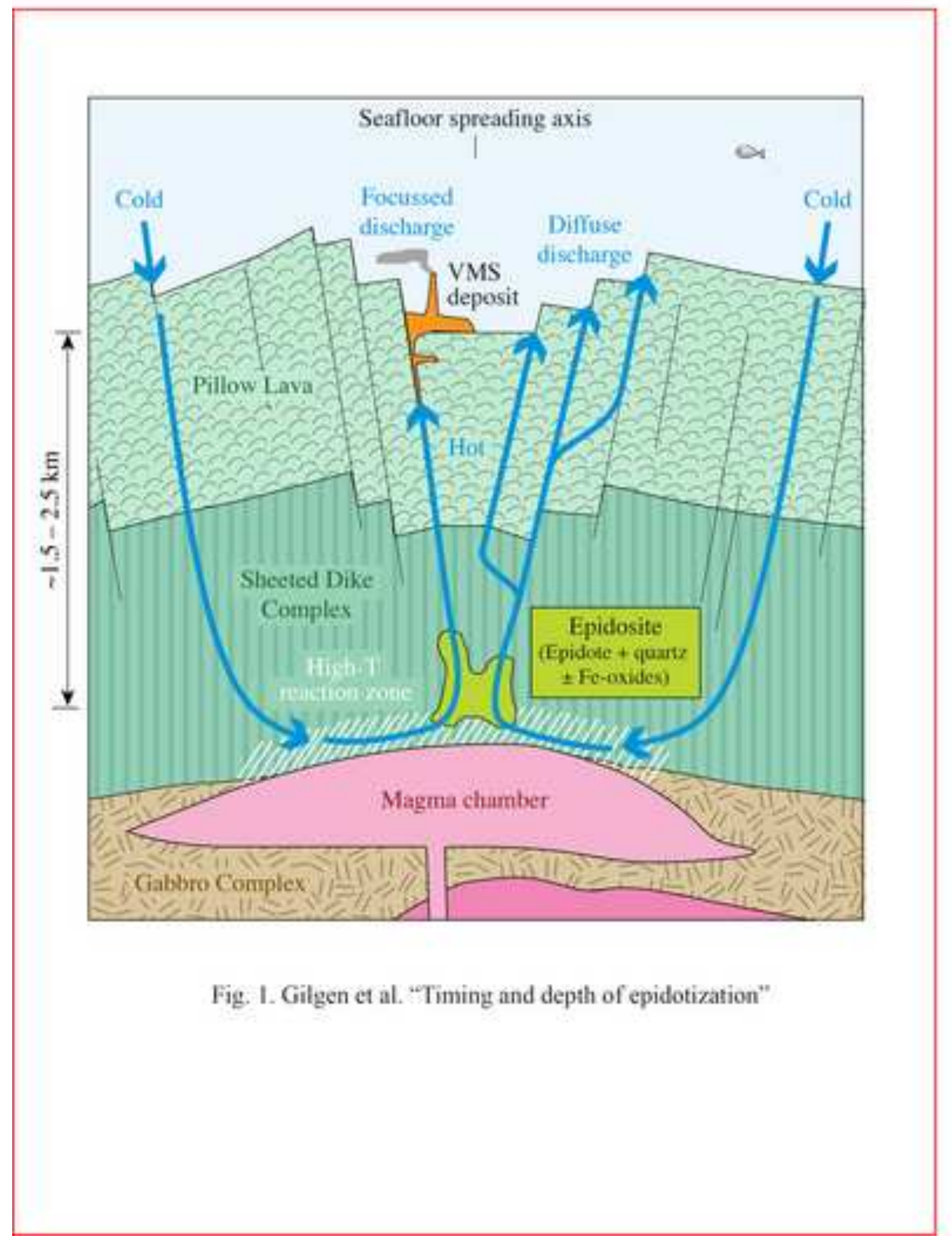




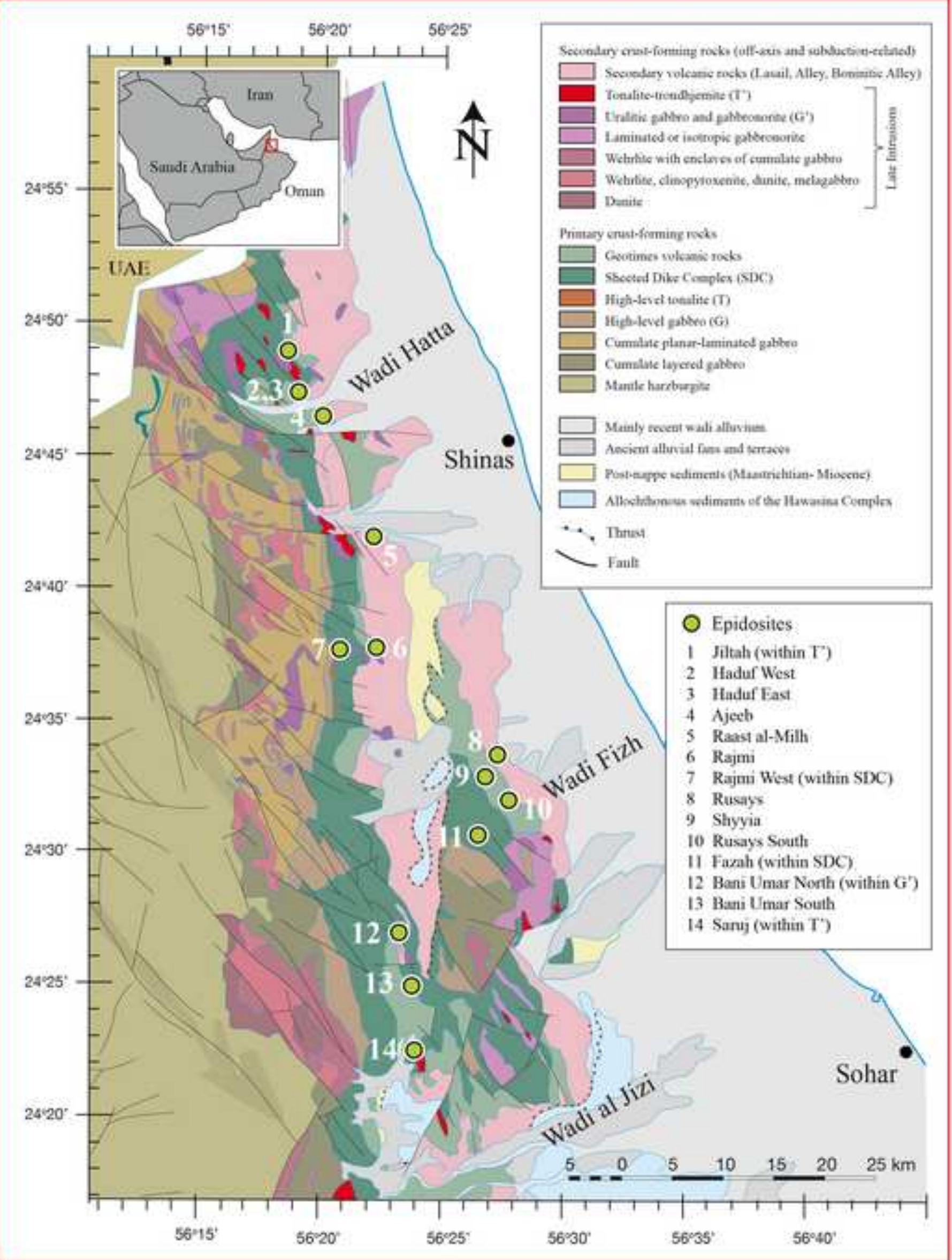

Fig. 2. Gilgen et al. "Timing and depth of epidotization" 


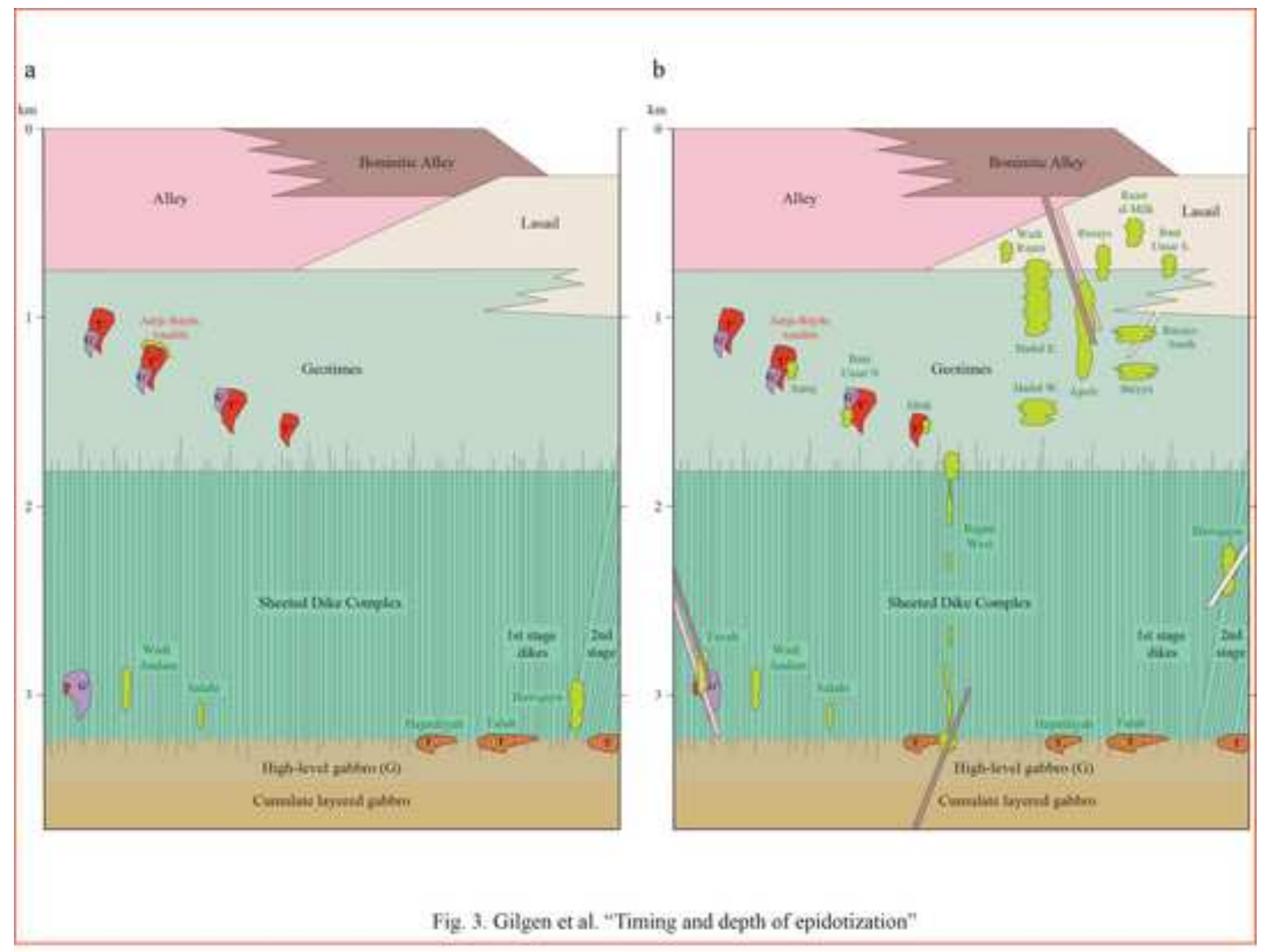

Figure 3

Fig. 3. Gilgen et al. "Timing and depth of epidotization" 
(a) Age data on intrusions G,T,G',T'

G,T (Rious 2012)

T(Thilon 198I; Rollinson 2009)

G.T (Riows 2013)

Haylayn I'-stage eprending (Roux 2013)

Haylays 2\%-stage spreading (Kooox 2013)

G.T in UAE (Gondenomgh 2010 )

$\mathrm{G}^{*}$ (Rioux 2013)

F (Warren 2005; Rollinson 2109)

$\mathrm{T}$ (Tilton 1281; Rolliamot 2009)

(b) Igncous activity

1. Sprowling-ridge phase

Staected Dike Complex (SDX)

Covtimes axial volcanisan

Figlt fevel Inimsions $(G, T)$

Lasul sif-axis velcanisal

2. Supvatumbluction sone phase

Alley volcanisan

fafe fintrusiom $\left(6^{\prime}, T^{\prime}\right)$

Houmitic Alley volcanism

(c) Volcanogenic Massive Sulfide deposits

(d) Epiclesites (permissible ages)

Wadi Andam (within SDC)

Salahi (within SDC)

Haduf West

Shivya

Rajmi West (within T and SDC)

Hajmiliyah (within $\mathrm{T}$ )

Falah (within T)

Rusays South

Hadur Eas

Bani Umar South

Rusays

Rajmi

Raast al-Milh

Hawqayn (within Haylayn $2^{-5}$ stige SDC)

Faah (within SDC)

Ajecb

Band Umar North (within G')

Jittalt (within T)

Saruj (wishin T')

(e) Obduction
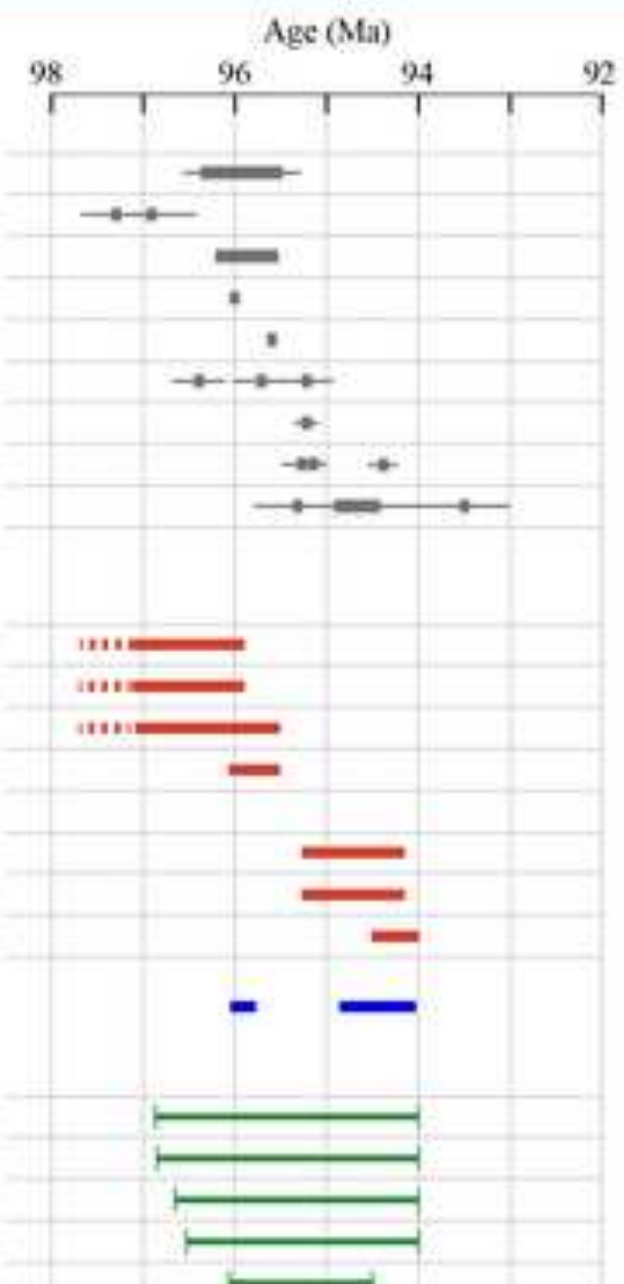

(2)
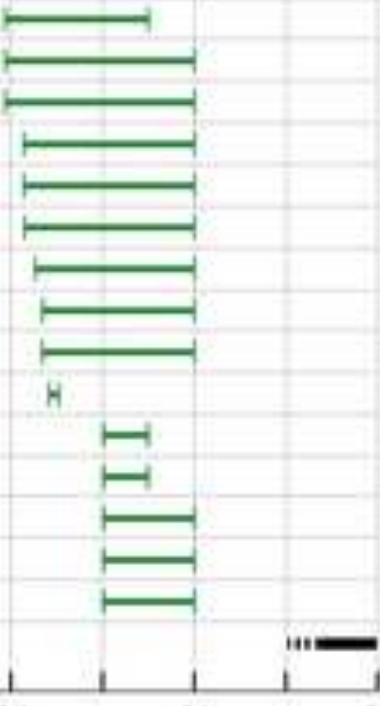

96

Age (Ma)

Fig. 4. Gilgen et al, "Timing and depth of epidotization" 
a

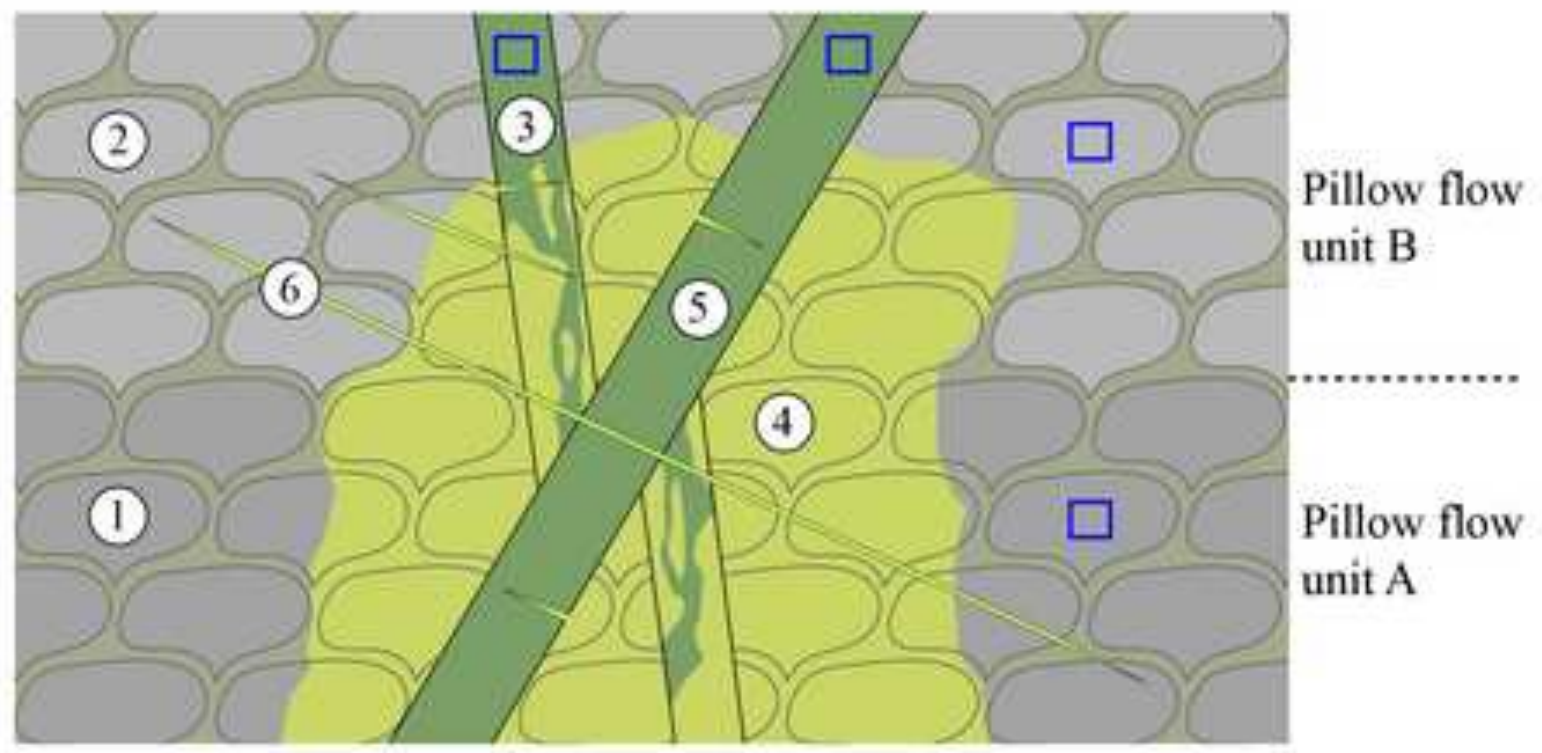

b Step I: Identify temporal sequence from cross-cutting relations in field:

(1) $\square$ Chl-alb altered pillows, flow unit A

(2) $\square$ Chl-alb altered pillows, flow unit B

(3) $\square$ Early chl-alb altered dikes

(4) $\square$ Pervasive epidosite (Ep-Qz-Ttn-Hem)

(5) Late chl-alb altered dike

(6) Epidote fracture-filling without epidosite selvage

Step II: Collect epidote-poor samples $\square$ from rocks that host pervasive epidosites Step III: Analyse relict clinopyroxenes \& immobile trace elements in epidote-poor samples Step IV: Compare field characteristics and analyses with literature data to identify volcanostratigraphic affiliation of different lavas and dike generations

Step V: Deduce timing of epidosite relative to igneous evolution

FIG 5. Gilgen et al. "Epidosite Timing" 

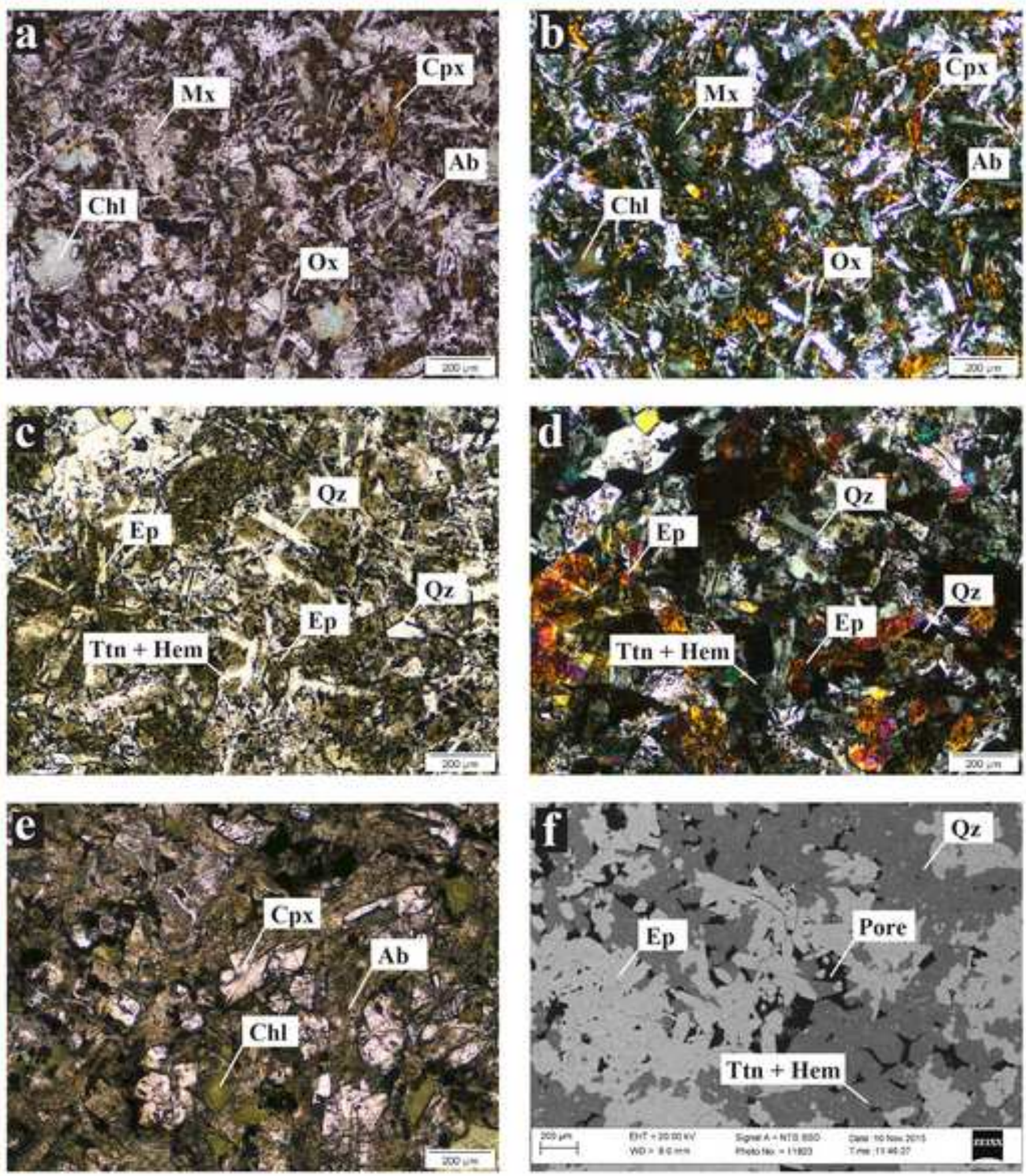

Fig. 6 Gilgen et al, "Timing and depth of epidotization" 
Figure 7
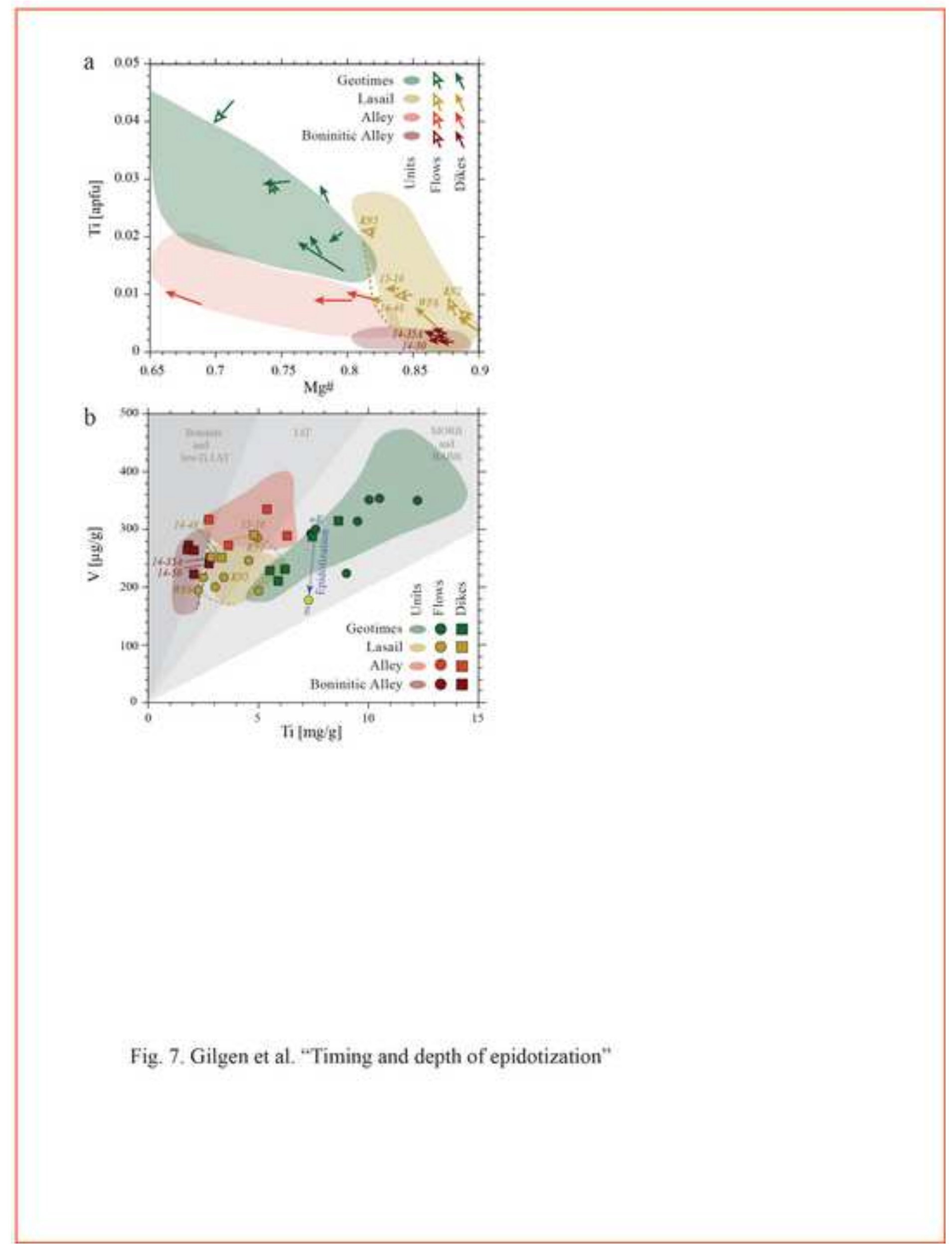

Fig. 7. Gilgen et al. "Timing and depth of epidotization"

Figure 7

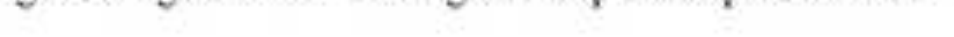




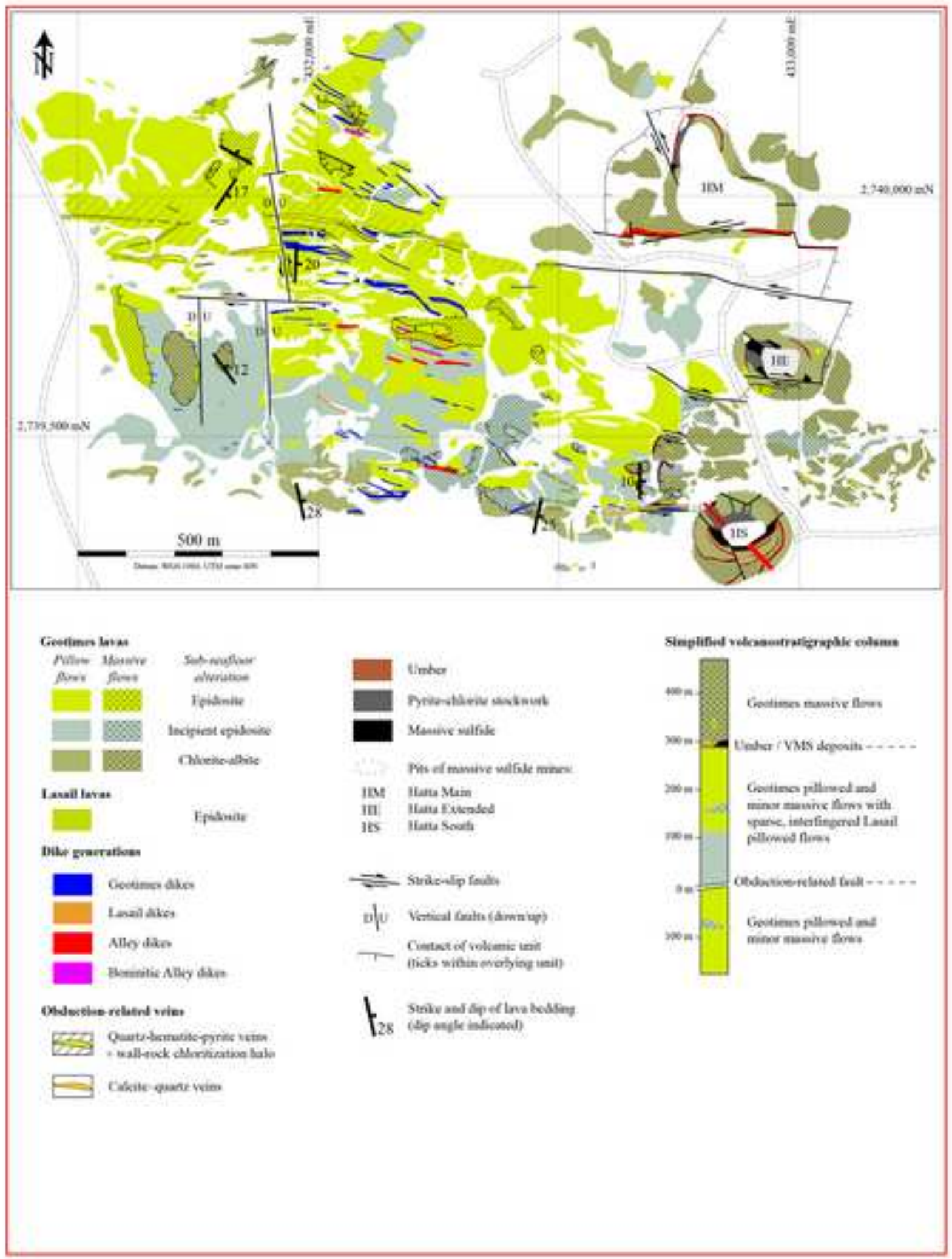

FIG 8 , Gilgen et al. "Timing and depth of epidotization" 

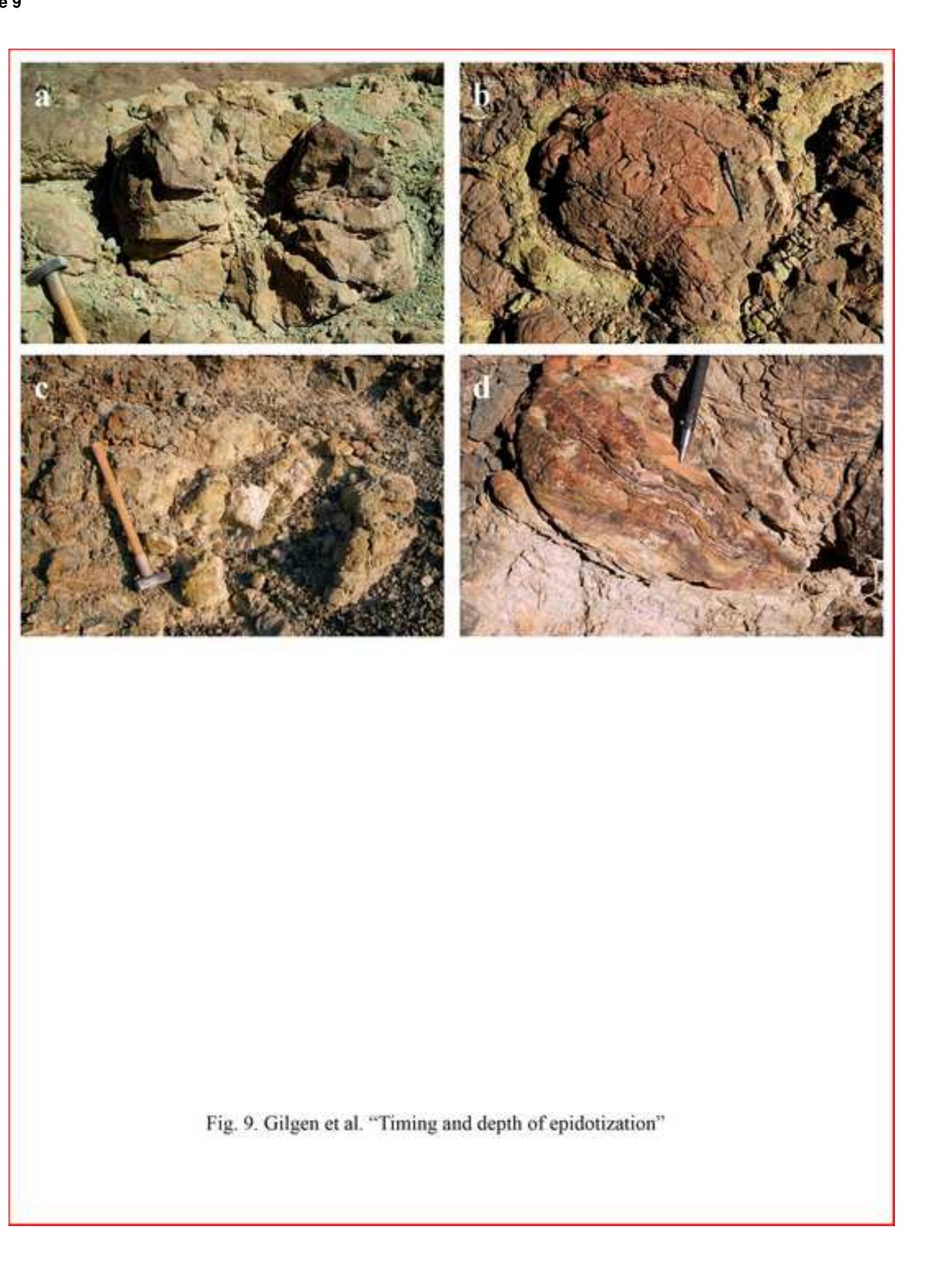

Fig. 9. Gilgen et al. "Timing and depth of epidotization"

\footnotetext{
rept
}

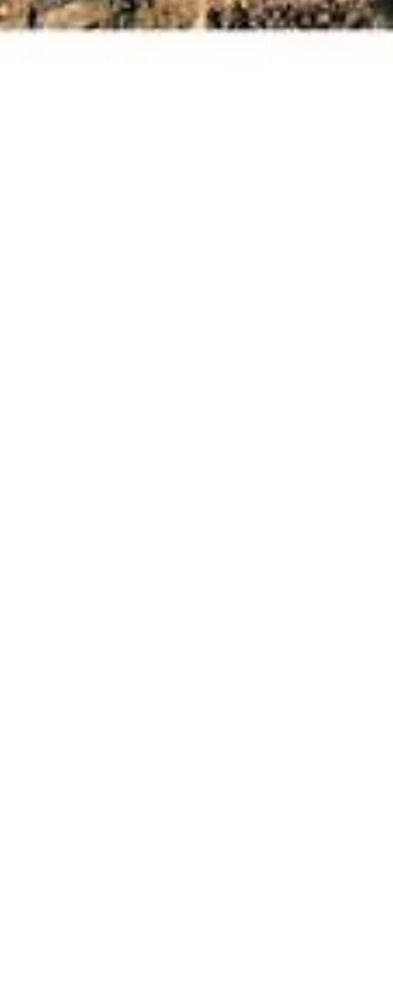



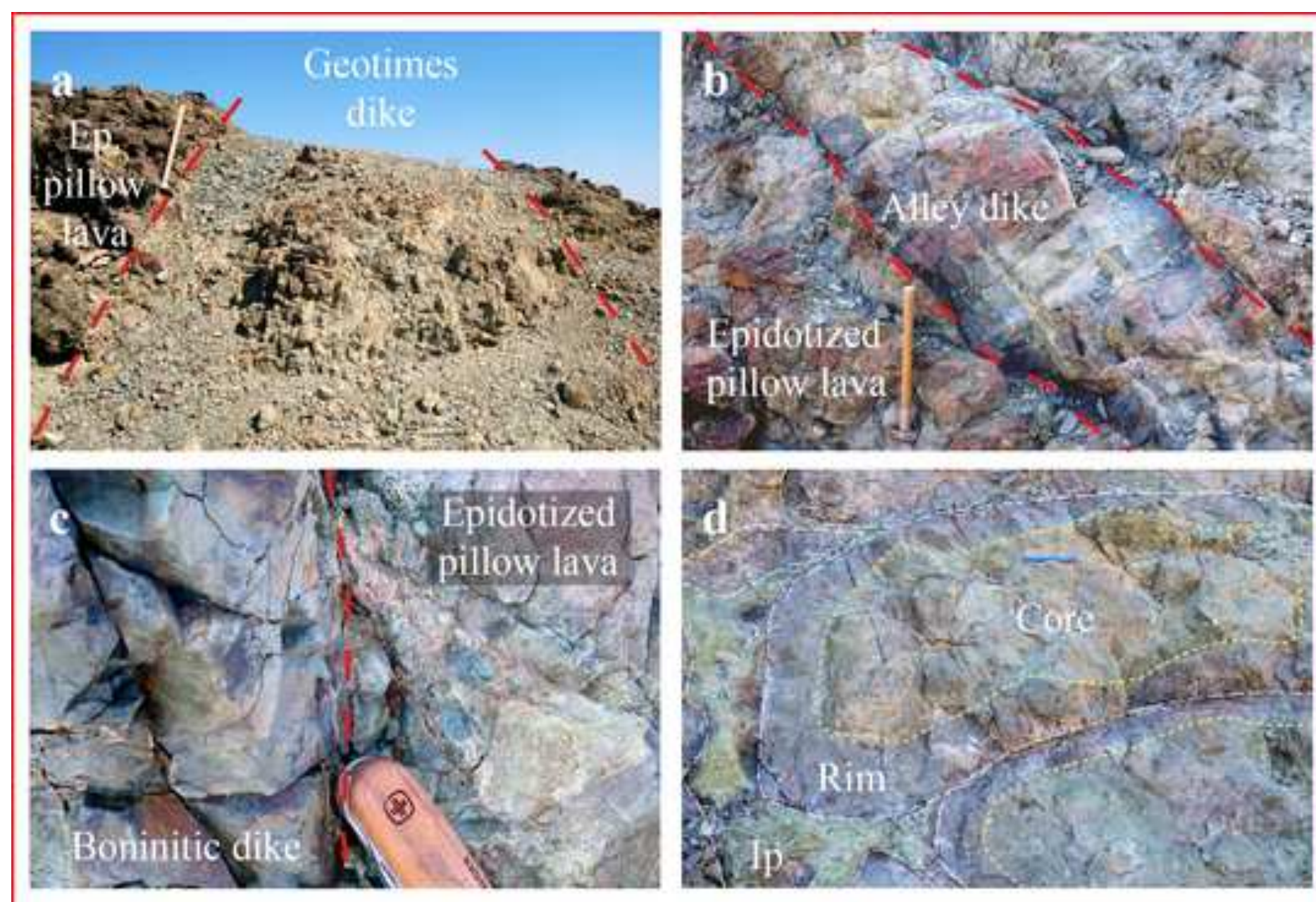

Fig. 10, Gilgen et al. "Timing and depth of epidotization"

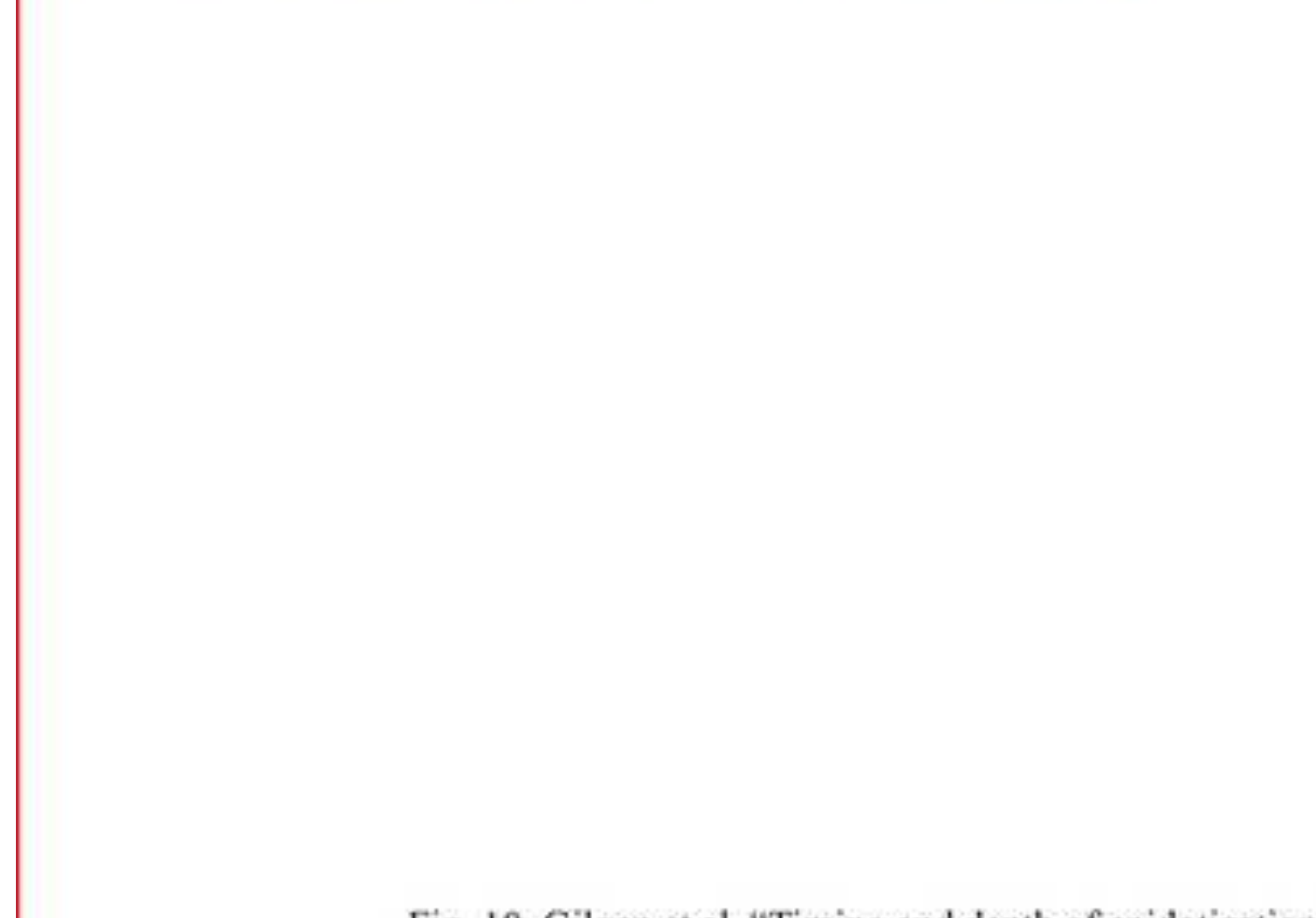

,

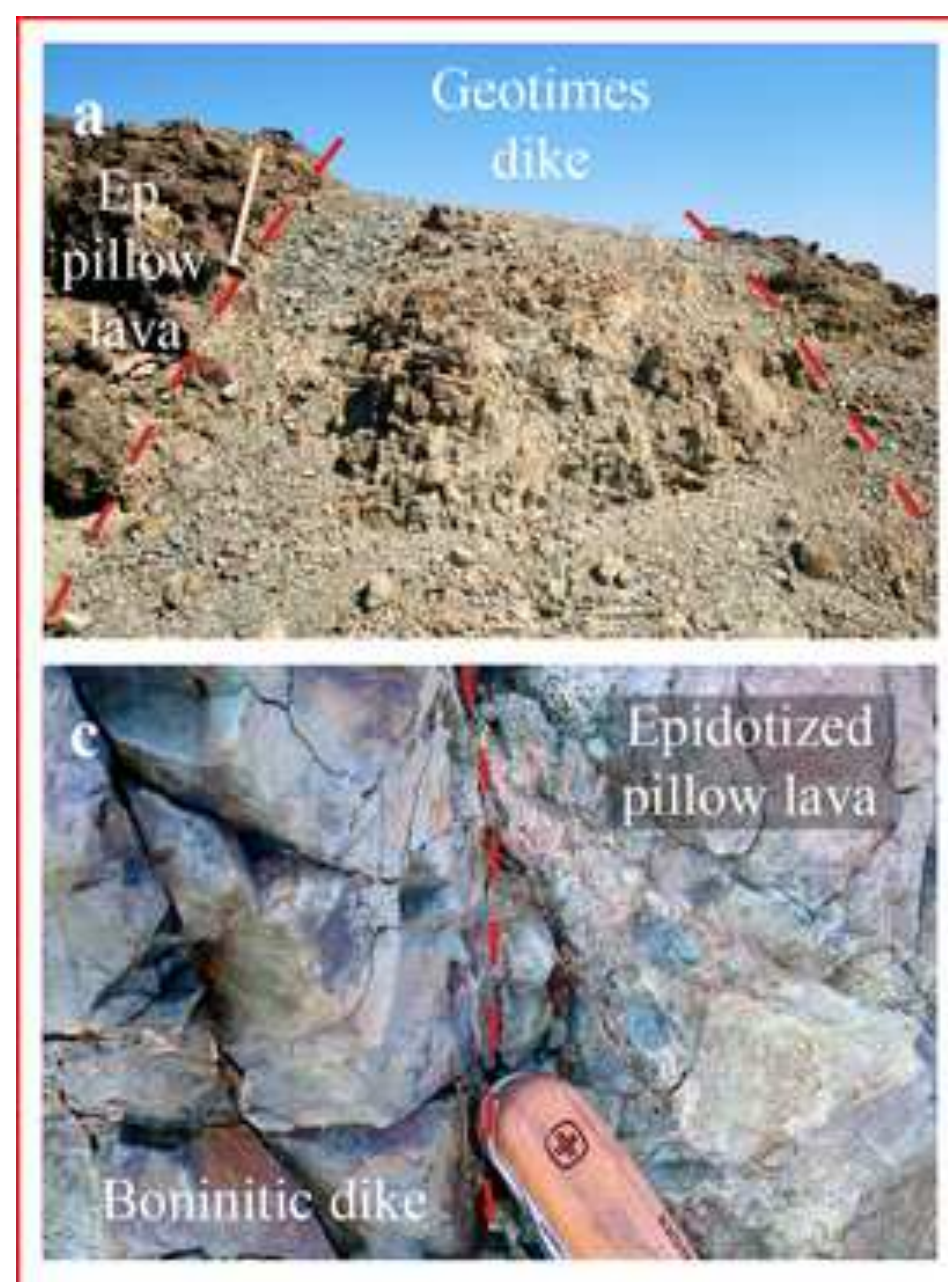

Figure 10

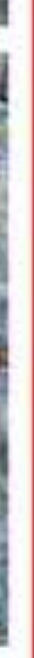

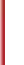



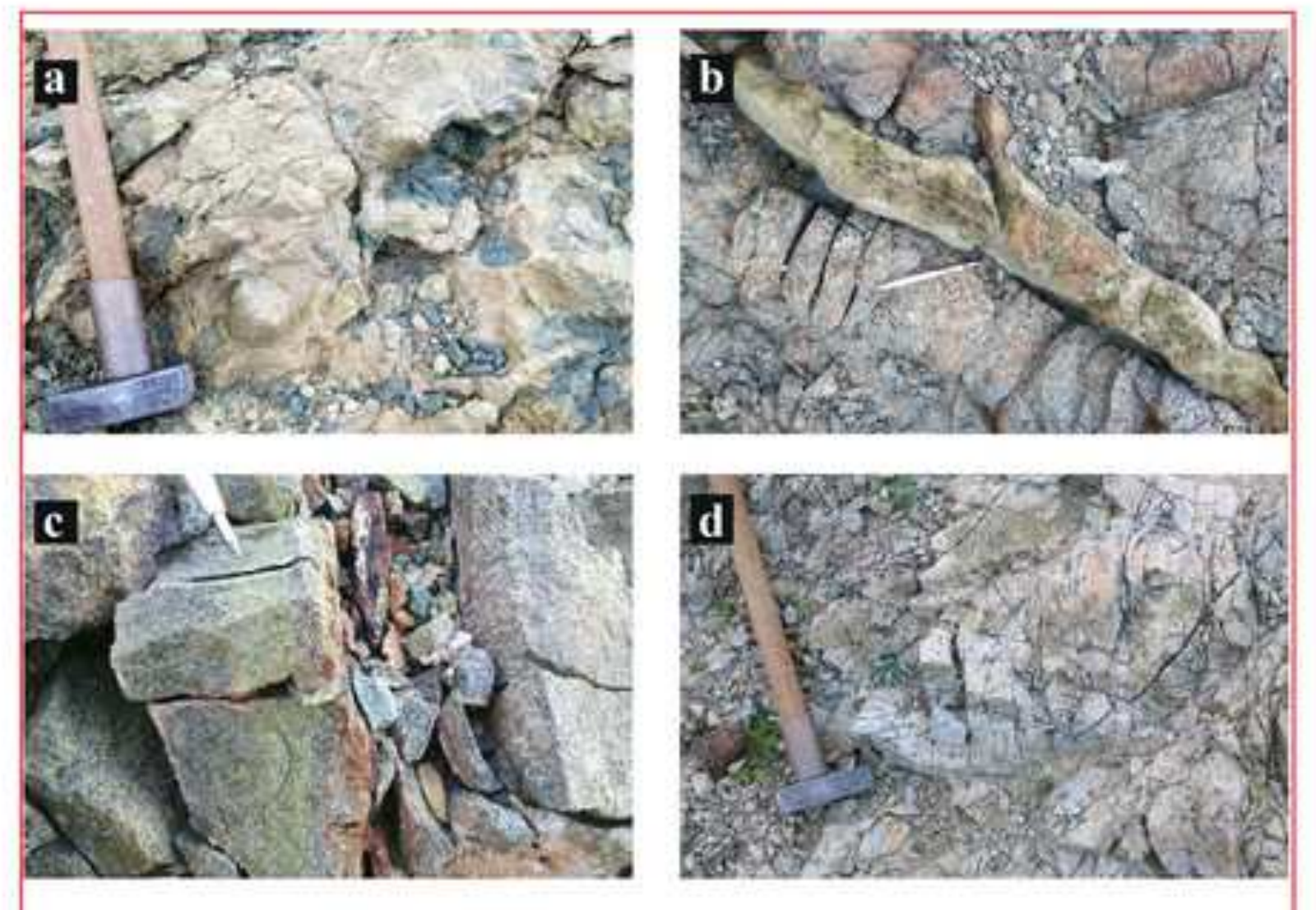

FIG 11. Gilgen et al. "Timing and depth of epidotization"

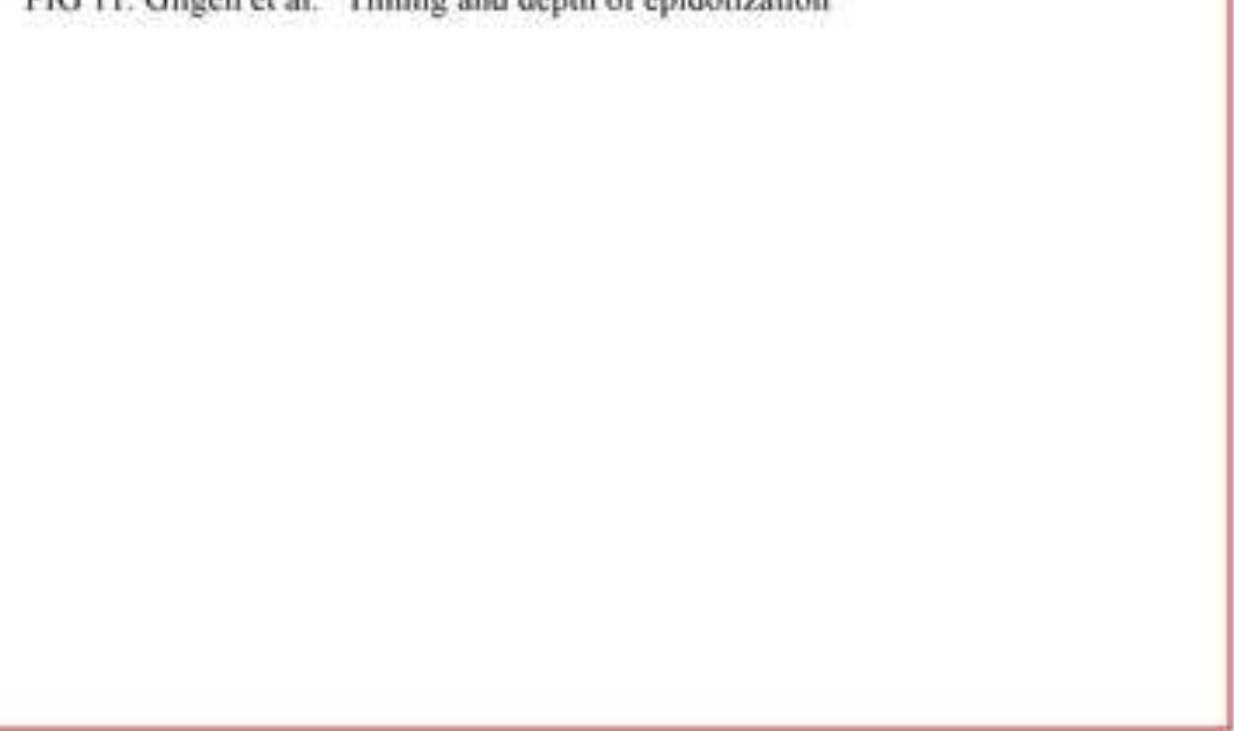


Figure 12
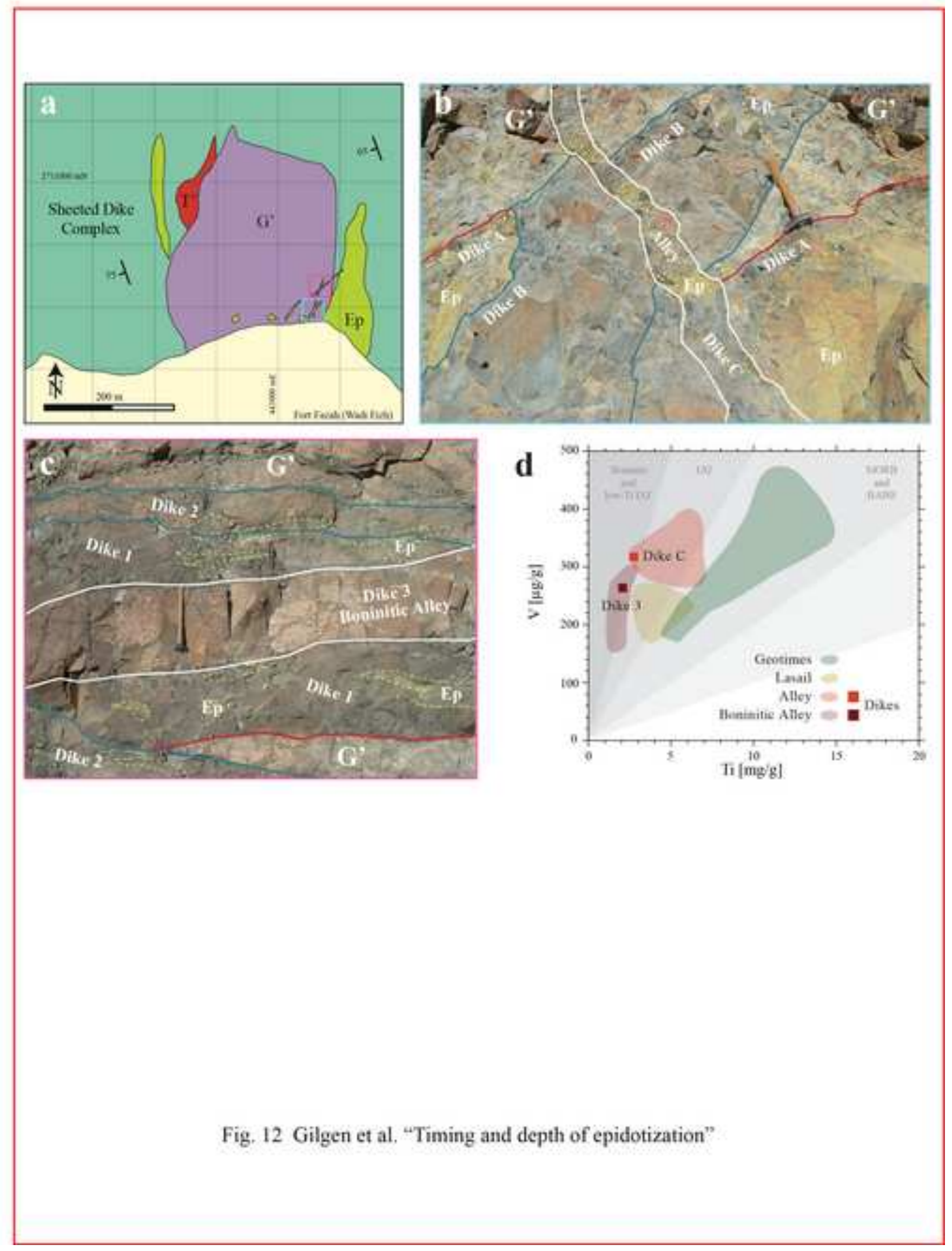

d
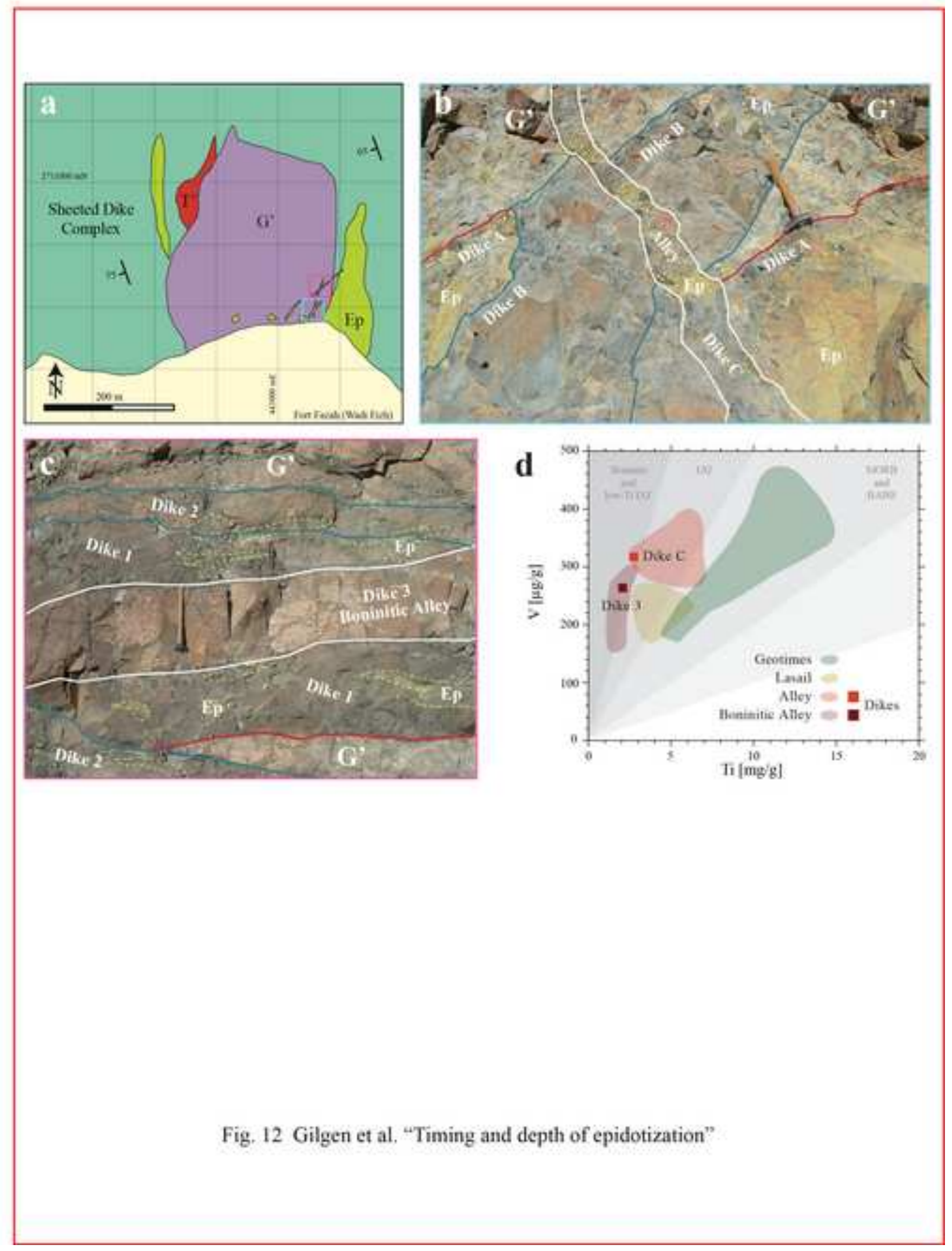

Fig. 12 Gilgen et al, "Timing and depth of epidotization"

\section{Figure 12}



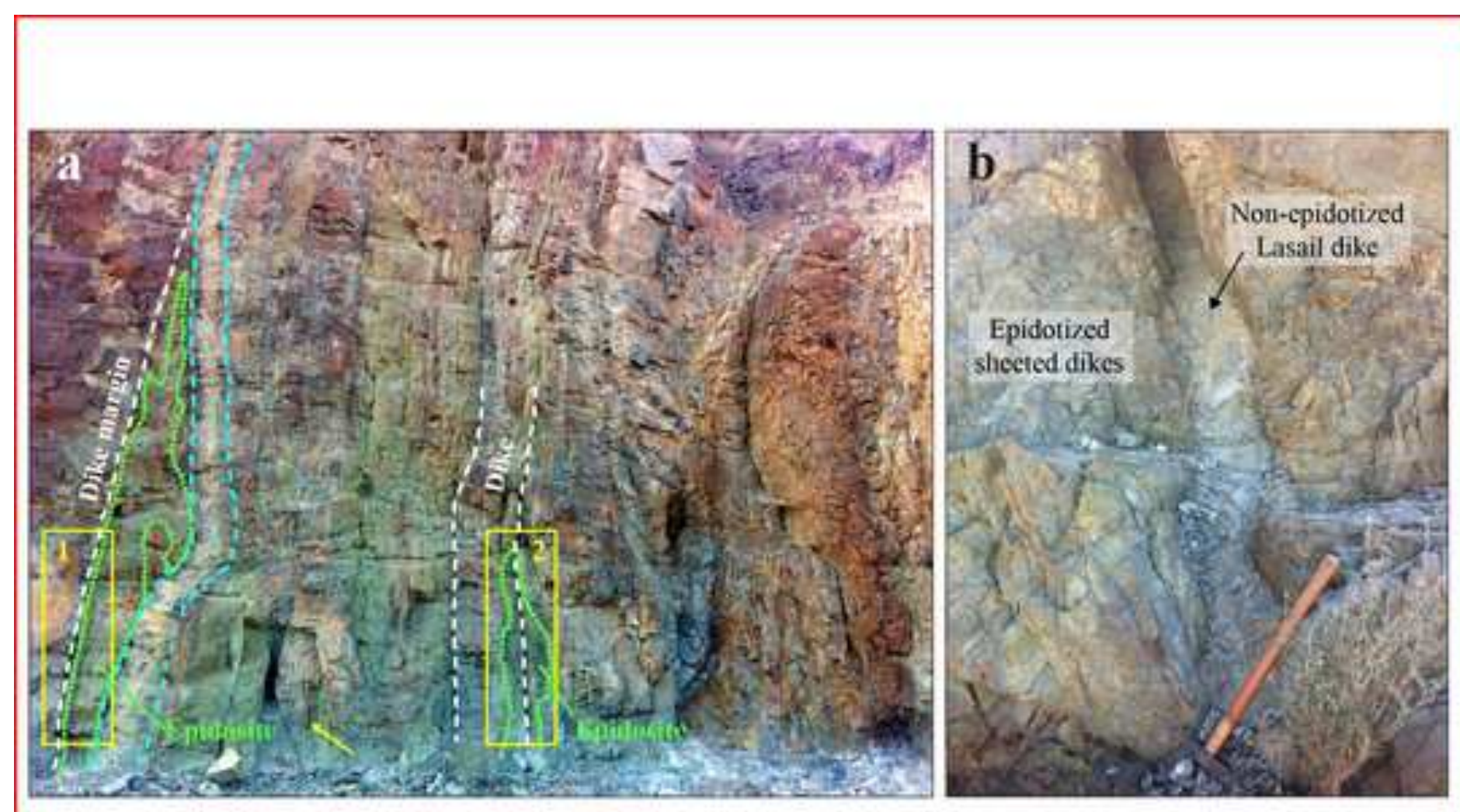

Fig. 13. Gilgen et al, "Timing and depth of epidotization"

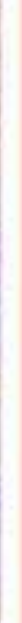

(3.) Gilgen etal "Timing and depth of epidotization"

\section{Figure 13}

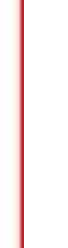

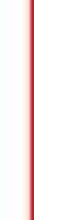

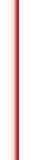

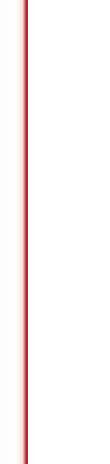

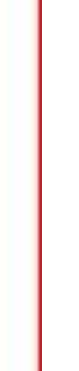

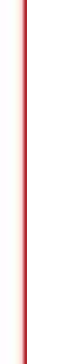

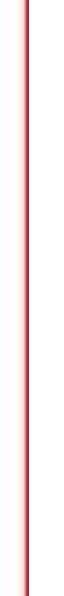

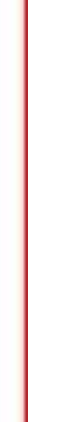

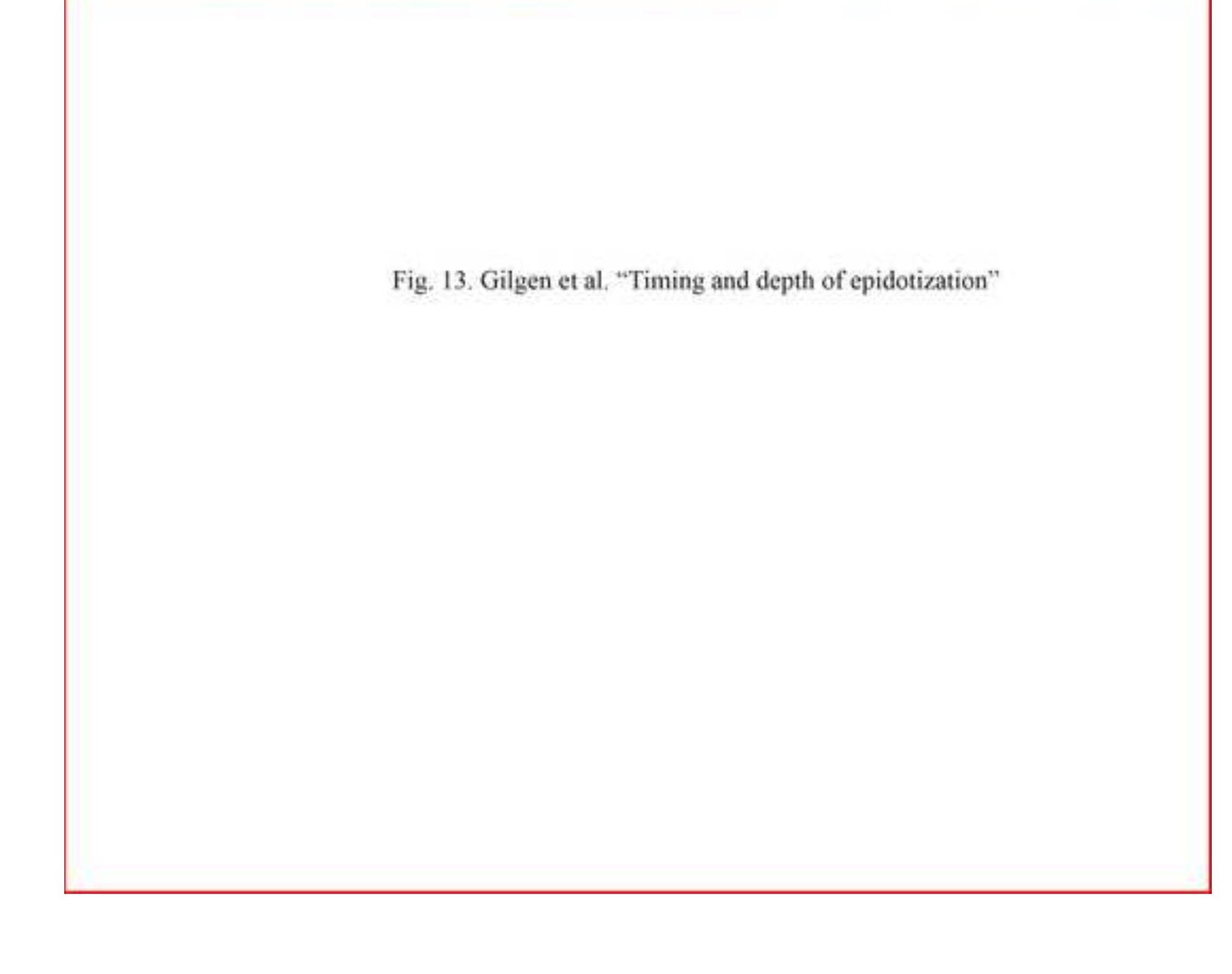

. 


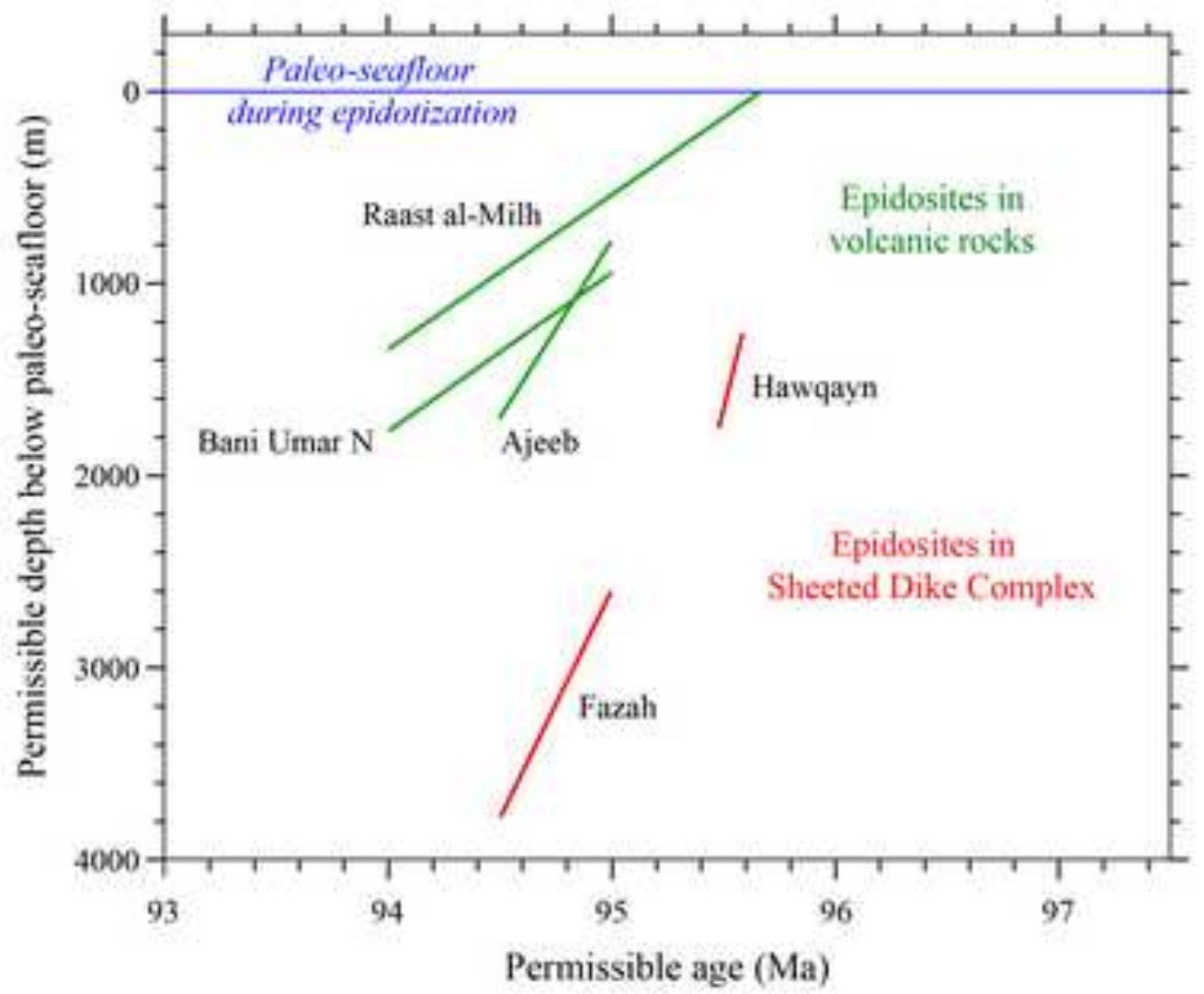

Fig. 14 Gilgen et al. "Timing and depth of epidotization" 
Table 1

\begin{tabular}{|c|c|c|c|c|c|c|c|c|c|c|c|c|c|c|c|c|c|c|c|c|c|c|c|c|c|c|c|c|c|c|c|c|c|c|c|c|c|c|}
\hline \multirow{2}{*}{$\begin{array}{c}\text { Volcani } \\
\text { c } \\
\text { Unit } \\
\end{array}$} & \multirow{2}{*}{$\begin{array}{l}\text { ii } \\
\text { Sample } \\
2 \text { number }\end{array}$} & \multirow[b]{2}{*}{ mple location } & \multirow{2}{*}{ Sample type $^{3}$} & \multicolumn{2}{|c|}{ UTM coordinates 40N } & \multirow{2}{*}{\multicolumn{2}{|c|}{$\begin{aligned} \mathrm{SiO}_{2} & \mathrm{TiO}_{2} \\
(\mathrm{w} \%) & (\mathrm{w}+\%)\end{aligned}$}} & \multirow{2}{*}{\multicolumn{2}{|c|}{$\begin{array}{l}\mathrm{Al}_{2} \mathrm{O}_{3} \quad \mathrm{Fe} \\
\mathrm{w} \text { wi } \%)(\mathrm{w}\end{array}$}} & \multirow{2}{*}{$\begin{array}{l}\text { Mno } \\
\left.\text { Mnt }{ }^{\prime}\right)\end{array}$} & \multirow{2}{*}{$\begin{array}{l}\mathrm{MgO} \\
(\mathrm{wt} \%)\end{array}$} & \multirow{2}{*}{$\begin{array}{l}\mathrm{CaO} \\
(\mathrm{wt} \%)\end{array}$} & \multirow{2}{*}{$\begin{array}{l}\mathrm{Na}_{2} \mathrm{O} \\
(\mathrm{wt} \%)\end{array}$} & \multirow{2}{*}{$\begin{array}{l}\mathrm{K}_{2} \mathrm{O} \\
(\mathrm{wt} \%)\end{array}$} & \multirow{2}{*}{$\begin{array}{r}\mathrm{P}_{2} \mathrm{O}_{5} \\
(\mathrm{wt} \%)\end{array}$} & \multirow{2}{*}{$\begin{array}{l}\text { Total } \\
\text { (wt \% }\end{array}$} & $\mathrm{R}$ & $\mathrm{Ba}$ & & $\mathrm{Nb}$ & $\mathrm{Zr}$ & $H_{1}$ & Y & Ga & $\mathrm{Zn}$ & Cu & $\mathrm{Ni}$ & Co & Cr & v & sc & La & $\mathrm{Ce}$ & $\mathrm{Nd}$ & $\mathrm{Pb}$ & Th & $\mathrm{U}$ & Ti \\
\hline & & & & & & & & & & & & & & & & & $(\mu \mathrm{g} / \mathrm{g})$ & $(\mu \mathrm{g} / \mathrm{g})$ & $(\mu \mathrm{g} / \mathrm{g})$ & $(\mu \mathrm{g} / \mathrm{g})$ & $(\mu \mathrm{g} / \mathrm{g})$ & $(\mu \mathrm{g} / \mathrm{g})$ & $(\mu \mathrm{g} / \mathrm{g})$ & $(\mu \mathrm{g} / \mathrm{g})$ & $(\mu \mathrm{g} / \mathrm{g})$ & $(\mu \mathrm{g} / \mathrm{g})$ & $(\mu \mathrm{g} / \mathrm{g})$ & $(\mu \mathrm{g} / \mathrm{g})$ & $(\mu \mathrm{g} / \mathrm{g})$ & $(\mu \mathrm{g} / \mathrm{g})$ & $(\mu \mathrm{g} / \mathrm{g})$ & $(\mu \mathrm{g} / \mathrm{g})$ & $(\mu \mathrm{g} / \mathrm{g})$ & $(\mu \mathrm{g} / \mathrm{g})$ & $(\mu \mathrm{g} / \mathrm{g})$ & $(\mu \mathrm{g} / \mathrm{g})$ & $(\mu \mathrm{g} / \mathrm{g})$ & $(\mathrm{m} g \mathrm{~g})$ \\
\hline & 13-34A & Aijecb & Dike & $\begin{array}{l}27939355 \\
273025\end{array}$ & 432010 & 52.77 & & 14.76 & 8.82 & 0.18 & 7.12 & 10.14 & 4.81 & 0.27 & & & 6.8 & 26.0 & 100.4 & n.d. & 61.4 & 5.1 & 24.8 & 17.7 & 67.5 & 47.2 & 83.2 & 43.5 & 197.0 & 235.7 & 42.0 & n.d. & 24.4 & 16.7 & 13.5 & n.d. & n.d. & 6.19 \\
\hline & 13-34B & Ajeeb & Dike & 2739355 & 432010 & 49.93 & 1.44 & 15.23 & 11.97 & 0.20 & 6.56 & 10.43 & 3.98 & 0.02 & 0.12 & 99.96 & 2.8 & n.d. & 43.1 & n.d. & 89.8 & 6.1 & 34.6 & 25.7 & 90.8 & 40.9 & 28.2 & 41.4 & 19.9 & 315.2 & 37.4 & n.d. & 31.5 & 18.9 & 11.8 & 0.1 & 0.3 & 8.62 \\
\hline & $13-44 \mathrm{~A}$ & $\begin{array}{l}\text { Ajeeb } \\
\text { Aiebb }\end{array}$ & $\begin{array}{c}\text { Dike } \\
\text { Dike }\end{array}$ & 0 & $\begin{array}{l}432053 \\
441377\end{array}$ & $\begin{array}{l}48.74 \\
55.05\end{array}$ & $\begin{array}{l}0.97 \\
124\end{array}$ & $\begin{array}{l}18.34 \\
15.61\end{array}$ & $\begin{array}{c}9.54 \\
1078\end{array}$ & $\begin{array}{l}0.22 \\
0.17\end{array}$ & $\begin{array}{l}8.22 \\
591\end{array}$ & $\begin{array}{l}10.72 \\
905\end{array}$ & $\begin{array}{l}2.96 \\
5.33\end{array}$ & $\begin{array}{l}0.20 \\
0.15\end{array}$ & $\begin{array}{l}0.08 \\
0.11\end{array}$ & $\begin{array}{l}100.10 \\
10041\end{array}$ & $\begin{array}{l}3.9 \\
4.1\end{array}$ & $\begin{array}{l}12.7 \\
176\end{array}$ & $\begin{array}{l}153.2 \\
149.1\end{array}$ & $\begin{array}{l}\text { n.d. } \\
\text { nd. }\end{array}$ & $\begin{array}{l}67.7 \\
77.7\end{array}$ & $\begin{array}{l}5.9 \\
50\end{array}$ & $\begin{array}{l}24.6 \\
311\end{array}$ & $\begin{array}{l}22.8 \\
203\end{array}$ & $\begin{array}{l}79.7 \\
794\end{array}$ & $\begin{array}{l}72.0 \\
446\end{array}$ & $\begin{array}{l}58.4 \\
208\end{array}$ & $\begin{array}{l}39.8 \\
789\end{array}$ & $\begin{array}{l}233.6 \\
108\end{array}$ & $\begin{array}{l}213.3 \\
2874\end{array}$ & 9 & $\begin{array}{l}\text { n.d. } \\
\text { nd. }\end{array}$ & 4 & $\begin{array}{l}16.7 \\
20.8\end{array}$ & 9.4 & n.d. & $\begin{array}{l}\text { n.d. } \\
\text { nd. }\end{array}$ & $\begin{array}{l}81 \\
44\end{array}$ \\
\hline & $\begin{array}{l}\begin{array}{l}144.4 \\
14-4\end{array} \\
\text { a }\end{array}$ & $\begin{array}{l}\text { Ajeeb } \\
\text { Ajeeb }\end{array}$ & $\begin{array}{l}\text { 变 } \\
\text { Dike }\end{array}$ & 9463 & $\begin{array}{l}\begin{array}{l}4311747 \\
431977\end{array} \\
4\end{array}$ & $\begin{array}{l}\begin{array}{l}22.03 \\
50.06\end{array} \\
\text { S }\end{array}$ & $\begin{array}{l}1.24 \\
0.91\end{array}$ & $\begin{array}{l}15.61 \\
16.71\end{array}$ & $\begin{array}{l}10.78 \\
9.00\end{array}$ & $\begin{array}{l}0.17 \\
0.24\end{array}$ & $\begin{array}{l}5.91 \\
9.89\end{array}$ & $\begin{array}{l}9.05 \\
9.27\end{array}$ & $\begin{array}{l}5.33 \\
4.12\end{array}$ & $\begin{array}{l}0.13 \\
0.05\end{array}$ & $\begin{array}{l}0.11 \\
0.07\end{array}$ & $\begin{array}{l}100.041 \\
10.37\end{array}$ & $\begin{array}{l}4.1 \\
2.7\end{array}$ & $\begin{array}{l}17.6 \\
23.5\end{array}$ & $\begin{array}{l}149.1 \\
126.7\end{array}$ & $\begin{array}{l}\text { n.d. } \\
\text { n.d. }\end{array}$ & $\begin{array}{l}75.7 \\
51.4\end{array}$ & $\begin{array}{l}5.0 \\
3.6\end{array}$ & $\begin{array}{l}31.1 \\
24.0\end{array}$ & 19.5 & $\begin{array}{l}79.4 \\
7122.5\end{array}$ & $\begin{array}{l}44.6 \\
61.1\end{array}$ & $\begin{array}{l}20.8 \\
90.5\end{array}$ & 83.9 & $\begin{array}{l}10.8 \\
306.9\end{array}$ & $\begin{array}{l}287.4 \\
2229.4\end{array}$ & $\begin{array}{l}35.6 \\
38.9\end{array}$ & $\begin{array}{l}\text { n.d. } \\
\text { n.d. }\end{array}$ & $\begin{array}{l}32.8 \\
27.0\end{array}$ & $\begin{array}{l}21.8 \\
17.6\end{array}$ & n.d. & 0.2 & n.d. & 7.44 \\
\hline & & Ajeeb & Massive flow 1 & & 805 & 48.51 & & 14.80 & 13.20 & 0.20 & & 10.03 & 3.93 & 0.16 & 8 & & $\begin{array}{l}2.1 \\
3.8\end{array}$ & 49.1 & $\begin{array}{l}120.7 \\
249.7\end{array}$ & $\begin{array}{l}\text { n...e } \\
\text { n.d. }\end{array}$ & 11.4 & $\begin{array}{l}3.0 \\
9.2\end{array}$ & 24.0 & 19.3 & 98.3 & 0.1 .1 & 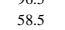 & 39.9 & 18 & & & n... & 0 & 21.4 & $\begin{array}{l}\text { n.t. } \\
10.9\end{array}$ & $\begin{array}{l}\text { n...e. } \\
\text { n.d. }\end{array}$ & n.a. & .28 \\
\hline & 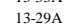 & Ajeeb & & & & 52.11 & 1.75 & 15.18 & 12.70 & 0.23 & 5 & 7.22 & 57 & 0.05 & 16 & 99.87 & 3.4 & n.d. & 78.4 & n.d. & 119.1 & 7.8 & 42.9 & 24.0 & 89.9 & & & & 8 & 353.1 & & id. & & & & & & 48 \\
\hline & & Ajeeb & & & 431965 & 53.43 & 1.67 & 14.41 & 11.75 & 0.17 & 4.29 & 8.84 & 5.16 & 0.03 & 0.16 & 100.00 & 2.5 & n.d. & 57.9 & n.d. & 111.4 & 6.4 & 40.0 & 21.9 & 75.0 & 82.3 & 20.4 & 35.9 & 26.0 & 354.2 & 32.7 & n.d. & 43.1 & 23.0 & 8.7 & n.d. & n.d. & 0.02 \\
\hline & $14-21$ & Bani Uma & h Pil & 85 & 438362 & 57.73 & 1.50 & 14.80 & 10.22 & 0.23 & 3.26 & 6.01 & 6.04 & 0.20 & 0.20 & 100.18 & 5.1 & 7.7 & 72.1 & 1.3 & 134.4 & 5.3 & 41.7 & 24.4 & 90.9 & 40.7 & 11.9 & 49.8 & 9.6 & 221.4 & 19.0 & n.d. & 61.7 & 29.0 & n.d. & 1.9 & n.d. & 9.00 \\
\hline & $\mathrm{wF}$ & & & & & $\begin{array}{r}51.23 \\
5530\end{array}$ & 1.58 & $\begin{array}{l}14.30 \\
1.81\end{array}$ & 13.11 & 0.17 & 11 & & 58 & & & & n.d. & 19.0 & 121.0 & n.d. & & n.a. & & n.a. & 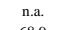 & 15.0 & & 76.0 & & & n.a. & & n.a. & n.a. & 7.0 & n.a. & n.a. & 47 \\
\hline & $16-4.5$ & & Pillow lav & 43821 & 430222 & 50.39 & ${ }^{1.23}$ & 16.81 & 12.21 & 0.40 & 7.76 & & 5.86 & ${ }^{0.06}$ & 0.11 & 99.96 & n.d. & 34.7 & 82.8 & 5.4 & 75.8 & 4.9 & 30.3 & 15.4 & 68.9 & 6.0 & 30.7 & 40.3 & & 291.8 & 38.8 & n.d. & 22.8 & 12.9 & 11.6 & 8.4 & n.d. & 7.37 \\
\hline & 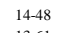 & Ajeeb & Dike & 2739593 & 4398 & 55.02 & 0.55 & 15.99 & 9.23 & 0.23 & 733 & 744 & 376 & 0.29 & 4 & & 4.7 & 7 & 119.1 & n.d. & 25.5 & 3.5 & 18.0 & 6 & th & 4 & 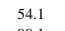 & 0 & & 9 & & d. & 18.5 & 14.8 & n.d. & 1.7 & n... & \\
\hline & $13-4$ & Ajeeb & & & $\begin{array}{l}432013 \\
438583\end{array}$ & 57.00 & 0.84 & 13.53 & 8.00 & 0.20 & & 7.97 & & $\begin{array}{l}0.02 \\
0.02\end{array}$ & 8 & & 4.5 & 26.8 & & 0.3 & & & 19.3 & & & & & & & & & d. & & & & id. & & 4 \\
\hline & $14-20$ & Bani Un & h Pill & 27 & 438586 & 52.56 & 0.76 & 16.80 & $\begin{array}{l}8.90 \\
.50\end{array}$ & 0.24 & 2 & 7.96 & 70 & 0.05 & 77 & 100.37 & 2.4 & 9.6 & 55.3 & 0.3 & 40.5 & 37 & 18 & 19.4 & 2 & 8 & ${ }_{4}^{4}$ & 2 & 105.6 & 243.2 & 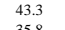 & n.d. & 28.4 & 18.1 & 0.5 & n.d. & 09 & \\
\hline & $\begin{array}{l}14-08 \\
15-01\end{array}$ & 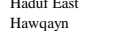 & $\begin{array}{l}{ }_{\mathrm{P}}^{\mathrm{P} 11} \\
\mathrm{Di}\end{array}$ & $\begin{array}{l}27171288 \\
2609158\end{array}$ & $\begin{array}{l}34119399 \\
539327\end{array}$ & $\begin{array}{l}56.93 \\
53.14\end{array}$ & $\begin{array}{l}0.51 \\
0.48\end{array}$ & $\begin{array}{l}16.28 \\
14.25\end{array}$ & $\begin{array}{l}8.59 \\
8.37\end{array}$ & $\begin{array}{l}0.23 \\
0.17\end{array}$ & $\begin{array}{l}7.03 \\
9.69\end{array}$ & $\begin{array}{l}3.40 \\
9.28\end{array}$ & 33 & $\begin{array}{l}0.03 \\
0.08\end{array}$ & $\begin{array}{l}0.04 \\
0.03\end{array}$ & $\begin{array}{l}100.0939 \\
99.82\end{array}$ & $\begin{array}{l}3.1 \\
2.1\end{array}$ & $\begin{array}{l}26.3 \\
26.7\end{array}$ & $\begin{array}{l}47.0 \\
76.0\end{array}$ & $\begin{array}{l}0.6 \\
6.9\end{array}$ & $\begin{array}{l}22.8 \\
27.4\end{array}$ & $\begin{array}{l}3.1 \\
1.7\end{array}$ & $\begin{array}{l}10.5 \\
12.5\end{array}$ & $\begin{array}{l}22.3 \\
12.7\end{array}$ & $\begin{array}{l}6.15 .1 \\
142.9\end{array}$ & $\begin{array}{l}19.1 \\
63.7\end{array}$ & $\begin{array}{l}14.7 \\
97.8\end{array}$ & $\begin{array}{l}42.9 \\
48.8\end{array}$ & $\begin{array}{l}31.5 \\
277.9\end{array}$ & $\begin{array}{l}204.9 \\
253.1\end{array}$ & $\begin{array}{l}33.8 \\
46.9\end{array}$ & $\begin{array}{l}\text { n.d. } \\
.1 .2\end{array}$ & $\begin{array}{c}13.9 \\
0.0\end{array}$ & $\begin{array}{l}3.5 .3 \\
7.7\end{array}$ & $\begin{array}{l}\text { no.de } \\
8.1\end{array}$ & $\begin{array}{l}\text { nnd.d. } \\
9.1\end{array}$ & $\begin{array}{l}0.8 \\
0.0\end{array}$ & 86 \\
\hline 4 & $\begin{array}{l}\text { Th-1010 } \\
\text { RaM10 }\end{array}$ & $\begin{array}{l}\text { Haw } \\
\text { Raas }\end{array}$ & $\begin{array}{l}\mathrm{D} \\
\text { Pil }\end{array}$ & $\begin{array}{l}2090158 \\
2730669\end{array}$ & 437328 & 54.06 & 0.41 & 15.23 & $\begin{array}{l}0.51 \\
7.52\end{array}$ & 0.12 & 8 & 8.69 & 5.78 & 0.15 & 0.03 & $\begin{array}{l}19.02 \\
101.67\end{array}$ & $\begin{array}{l}2.1 . \\
\text { n.d. }\end{array}$ & 14.0 & 110.0 & n.d. & 27.0 & n.a. & 12.0 & .a. & a. & 15.0 & 142.0 & $\begin{array}{l}+40.8 \\
54.0\end{array}$ & 410.0 & $\begin{array}{l}218.1 \\
218.0\end{array}$ & n... & 1.a. & na. & n.a. & $\begin{array}{l}\text { o. } \\
\text { n.d. }\end{array}$ & n... & na. & 46 \\
\hline & WF6 & & & & 44 & 53.78 & 0.36 & 13.48 & 8.26 & 0.14 & & 9.50 & 3.68 & 0.36 & 0.04 & 100.69 & $\begin{array}{l}\text { h.d. } \\
\text { n.d. }\end{array}$ & 0 & 151.0 & $\begin{array}{l}\text { H..u. } \\
\text { n.d. }\end{array}$ & 23.0 & $\begin{array}{l}\text { n.a. } \\
\text { n.a. }\end{array}$ & 12.0 & a. & a. & & $\begin{array}{l}242.0 \\
232.0\end{array}$ & 61.0 & 622.0 & 196.0 & n & & n.a. & $\begin{array}{l}\text { ha.a. } \\
\text { n.a. }\end{array}$ & 8.0 & 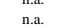 & $\begin{array}{l}\text { na.a. } \\
\text { n.a. }\end{array}$ & 2.16 \\
\hline & $15-16$ & & & & 445134 & 52.21 & 0.80 & 16.28 & 10.15 & 0.23 & 8 & 8.05 & 2.70 & 0.25 & 0.06 & 99.53 & 5.0 & 30.6 & 118.2 & 6.9 & 45.7 & 0.0 & 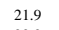 & 5.5 & 67.3 & 114.5 & 40.2 & 45.2 & 36.3 & 290.3 & 41.1 & 0.0 & 0 & 9.6 & 5.7 & 6.5 & 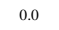 & a \\
\hline & RN2 & & & & & 52.62 & & & 7.86 & 0.14 & 2 & 12.97 & & 0.08 & & & n.d. & n.d. & 10 & n.d. & 53.0 & n.a. & 22.0 & n.a. & ent & 22.0 & & 46.0 & 277.0 & 285.0 & n.a. & a. & n.a. & n.a. & n.d. & a. & a. & 98 \\
\hline & RN5 & Wadi Raj & Pillow la & 2725434 & 435566 & 51.44 & 0.57 & 14.15 & 8.03 & 0.19 & 8.98 & 12.87 & 5.48 & 0.14 & 0.07 & 102.02 & n.d. & 17.0 & 49.0 & n.d. & 34.0 & n.a. & 18.0 & n.a. & n.a. & 64.0 & 190.0 & 57.0 & 504.0 & 219.0 & & 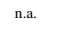 & n.a. & n.a. & n.d. & n.a. & n.a. & 42 \\
\hline & $13-45$ & Aije & & 2739615 & & 51.64 & 0.89 & 16.30 & 12.09 & 0.21 & 7.06 & 9.49 & 2.02 & 0.09 & 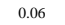 & & 3.5 & 24.2 & 3 & n.d. & 42.5 & 4.2 & 24.0 & 9 & 1.4 & 90.1 & 7.3 & .4 & 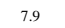 & 3 & 44.5 & n.d. & 19.4 & 9 & 10.9 & n.d. & n.d. & 5.35 \\
\hline द & $14-5$ & $\begin{array}{l}\text { Ajec } \\
\text { Aide }\end{array}$ & & & & $\begin{array}{l}51.66 \\
53.21\end{array}$ & & & & & & & & & & & 3 & & & 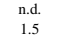 & & & & & & & & & & & & & & & & & & \\
\hline & $15-09$ & $\begin{array}{l}\text { Ajeeb } \\
\text { Fazahh }\end{array}$ & $\begin{array}{l}\text { Dike } \\
\text { Dike }\end{array}$ & 2710781 & $\begin{array}{l}4311776 \\
443040\end{array}$ & $\begin{array}{l}53.21 \\
56.49\end{array}$ & $\begin{array}{l}0.61 \\
0.46\end{array}$ & $\begin{array}{l}16.49 \\
15.13\end{array}$ & $\begin{array}{r}9.84 \\
10.25\end{array}$ & $\begin{array}{l}0.21 \\
0.06\end{array}$ & 3.31 & $\begin{array}{l}9.69 \\
11.79\end{array}$ & $\begin{array}{l}2.30 \\
0.07\end{array}$ & $\begin{array}{l}0.20 \\
0.01\end{array}$ & $\begin{array}{l}0.04 \\
0.04\end{array}$ & $\begin{array}{l}10.026 \\
97.61\end{array}$ & $\begin{array}{l}3.0 \\
3.4\end{array}$ & $\begin{array}{l}31.7 \\
24.7\end{array}$ & 183.3 & 7.2 & 32.3 & 4.2 & 14.2 & 19.3 & 14.1 & 6.6 & 18.8 & 60.9 & $\begin{array}{l}145.3 \\
0.0\end{array}$ & $\begin{array}{l}270.0 \\
317.2\end{array}$ & $\begin{array}{l}33.6 \\
33.4\end{array}$ & 0.4 & 22.0 & 6.5 & 0.0 & 3.1 & 0.0 & .73 \\
\hline & $14-31$ & Ajec & Dit & 2739890 & 431784 & 56.00 & 0.34 & 14.70 & 8.60 & 0.18 & 8.87 & 7.35 & 3.84 & 0.31 & 0.02 & 100.24 & 4.2 & 37.0 & 146.7 & 1.2 & 13.8 & 2.2 & 12.3 & 16.2 & 71.2 & 169.7 & 55.4 & 60.0 & 191.4 & 222.8 & 42.2 & n.d. & 6.6 & 10.7 & n.d. & n.d. & 0.5 & 2.04 \\
\hline & $14-35 \mathrm{~A}$ & & $\begin{array}{l}\text { Dikie (post- } \\
\text { epidotization) }\end{array}$ & & & 54.25 & 0.48 & 16.49 & 9.33 & 0.25 & 7.83 & 6.23 & 5.05 & 0.23 & 0.03 & 100.19 & 4.8 & 39.5 & 127.1 & 0.6 & 20.4 & 3.2 & 16.2 & 18.7 & 153.2 & 98.2 & 32.6 & 43.3 & 76.6 & 251.3 & 39.8 & n.d. & 31.1 & 19.2 & n.d. & n.d. & n.d. & .87 \\
\hline & 1450 & Ajeeb & $\begin{array}{l}\text { Dike (pos } \\
\text { eepidotizat }\end{array}$ & 2739467 & 431888 & 54.76 & 0.48 & 16.34 & 9.22 & 0.27 & 8.24 & 7.24 & 2.98 & 0.37 & 0.03 & 99.93 & 5.9 & 25.0 & 105.5 & n.d. & 21.1 & 2.6 & 15.4 & 18.3 & 169.9 & 110.4 & 29.2 & 51.1 & 70.6 & 241.9 & 38.2 & n.d. & 31.7 & 19.4 & 0.8 & n.d. & n.d. & .87 \\
\hline 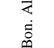 & $15-06$ & Fazal & $\begin{array}{l}\text { Dike (po } \\
\text { epidotiza }\end{array}$ & 2710820 & 443031 & 54.55 & 0.34 & 15.87 & 9.23 & 0.13 & 7.21 & 8.86 & 2.98 & 0.34 & 0.02 & 99.56 & 3.3 & 43.3 & 112.5 & 8.4 & 22.7 & 4.7 & 11.8 & 13.7 & 22.0 & 7.0 & 55.6 & 68.0 & 104.5 & 263.8 & 43.9 & 0.0 & 23.3 & 11.3 & 2.9 & 5.1 & 0.0 & .03 \\
\hline & & & $\begin{array}{l}\text { Dike (post- } \\
\text { epidotization) }\end{array}$ & & 4332 & 54.68 & 0.29 & 14.77 & 8.89 & 0.16 & 8.26 & 10.73 & 1.57 & 0.07 & 0.02 & 99.48 & 2.6 & 8.9 & 82.4 & 7.8 & 20.0 & 0.0 & 11.0 & 13.5 & 72.8 & 121.2 & 81.1 & 59.7 & 232.8 & 5.6 & 46.0 & 0.0 & 0.1 & 3.1 & 4.8 & 4.9 & 0.0 & 74 \\
\hline & TB05 & Rajmi West & $\begin{array}{l}\text { Dike } \\
\text { evidd }\end{array}$ & 2723734 & 433211 & 53.26 & 0.30 & 14.11 & 9.14 & 0.17 & 8.99 & 10.03 & 2.42 & 0.11 & 0.01 & 98.56 & 3.1 & 34.0 & 106.4 & 6.9 & 16.3 & 0.0 & 11.4 & 11.6 & 74.4 & 179.4 & 79.2 & 60.3 & 230.6 & 273.1 & 48.2 & 0.0 & 0.0 & 3.7 & 4.7 & 3.7 & 0.0 & 1.77 \\
\hline
\end{tabular}

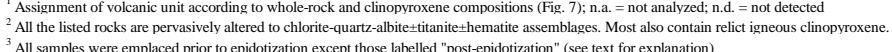


Gilgen et al. "Timing and depth of epidotization"

Table 2

Electron-microprobe analyses of clinopyroxene crystals in epidote-poor lavas and dike:

\begin{tabular}{|c|c|c|c|c|c|c|c|}
\hline $\begin{array}{l}\text { Volcani } \\
\text { c Unit }{ }^{1,2}\end{array}$ & $\begin{array}{l}\text { Sample } \\
\text { number }\end{array}$ & Sample location & Sample type & $n^{4}$ & $\begin{array}{c}\mathrm{SiO}_{2} \\
(\text { wt \%) }\end{array}$ & $\begin{array}{c}\mathrm{CaO} \\
(\mathrm{wt} \%)\end{array}$ & $\begin{array}{l}\mathrm{Na}_{2} \mathrm{O} \\
(\mathrm{wt} \%)\end{array}$ \\
\hline \multirow{7}{*}{ 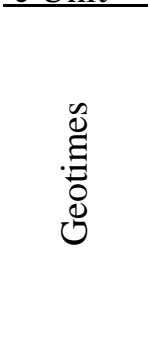 } & $13-34 \mathrm{~A}$ & Ajeeb & Dike & 49 & 52.23 & 18.83 & 0.06 \\
\hline & $13-34 B$ & Ajeeb & Dike & 40 & 50.38 & 19.56 & 0.08 \\
\hline & $14-43$ & Ajeeb & Dike & 136 & 50.65 & 20.41 & 0.25 \\
\hline & $14-49$ & Ajeeb & Dike & 84 & 49.11 & 21.41 & 0.28 \\
\hline & $13-33 \mathrm{~A}$ & Ajeeb & Massive flov & 53 & 49.28 & 19.99 & 0.12 \\
\hline & $13-29 \mathrm{~A}$ & Ajeeb & Pillow lava & 48 & 50.39 & 18.86 & 0.09 \\
\hline & WF8 & Rusays & Pillow lava & 57 & 50.32 & 20.30 & 0.31 \\
\hline \multirow{8}{*}{ 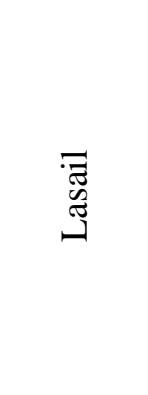 } & $14-48$ & Ajeeb & Dike & 82 & 51.76 & 20.41 & 0.13 \\
\hline & $14-20$ & Bani Umar Soutr & Pillow lava & 21 & 52.41 & 22.00 & 0.15 \\
\hline & $15-01$ & Hawqayn & Dike & 79 & 52.80 & 21.41 & 0.12 \\
\hline & RaM10 & Raast al-Milh & Pillow lava & 91 & 51.10 & 18.98 & 0.13 \\
\hline & WF6 & Rusays & Pillow lava & 46 & 50.03 & 19.77 & 0.15 \\
\hline & $15-16$ & Rusays & Dike & 45 & 51.19 & 20.62 & 0.14 \\
\hline & $\mathrm{RN} 2$ & Wadi Rajmi & Pillow lava & 77 & 47.42 & 22.75 & 0.17 \\
\hline & RN5 & Wadi Rajmi & Pillow lava & 45 & 52.20 & 21.51 & 0.18 \\
\hline \multirow{3}{*}{ 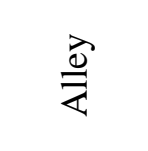 } & $13-45$ & Ajeeb & Dike & 54 & 52.65 & 19.38 & 0.04 \\
\hline & $14-51$ & Ajeeb & Dike & 77 & 51.02 & 20.09 & 0.19 \\
\hline & $14-52$ & Ajeeb & Dike & 112 & 51.84 & 19.44 & 0.13 \\
\hline \multirow{5}{*}{ 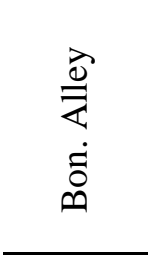 } & $14-31$ & Ajeeb & Dike & 91 & 53.04 & 19.45 & 0.09 \\
\hline & $14-35 \mathrm{~A}$ & Ajeeb & Dike & 84 & 53.29 & 20.59 & 0.09 \\
\hline & $14-50$ & Ajeeb & Dike & 99 & 52.73 & 20.98 & 0.11 \\
\hline & ТВ02 & Rajmi West & Dike & 95 & 53.34 & 20.69 & 0.05 \\
\hline & TB05 & Rajmi West & Dike & 69 & 53.11 & 19.35 & 0.05 \\
\hline
\end{tabular}

${ }^{1}$ Assignment of volcanic unit according to whole-rock and clinopyroxene composition

${ }^{2}$ All the listed rocks are pervasively altered to chlorite-quartz-albite \pm epidote \pm titanite \pm 1

${ }^{3}$ All samples were emplaced prior to epidotization except those labelled "post-epidotiz

${ }^{4}$ Values represent the median of $n$ samples; Assignment of volcanic unit according to 
Table 3

Estimated minimum and maximum depths of sub-seafloor epidotization

\begin{tabular}{|c|c|c|c|c|}
\hline $\begin{array}{l}\text { Epidosite } \\
\text { locality }\end{array}$ & $\begin{array}{l}\text { Stratigraphic distance to } \\
\text { sheeted-dike/Geotimes } \\
\text { boundary }{ }^{1} \\
\text { (m) }\end{array}$ & $\begin{array}{c}\text { Presence } \\
\text { of Lasail } \\
\text { above? }\end{array}$ & $\begin{array}{l}\text { Minimum depth } \\
\text { below } \\
\text { paleo-seafloor } \\
\text { (m) }\end{array}$ & $\begin{array}{l}\text { Maximum depth } \\
\text { below } \\
\text { paleo-seafloor } \\
\text { (m) }\end{array}$ \\
\hline \multicolumn{5}{|c|}{ Epidosites at stratigraphic level of extrusive rocks } \\
\hline Ajeeb & 750 & yes & 780 & 1700 \\
\hline Bani Umar N & 200 & no & 944 & 1770 \\
\hline Bani Umar S & 1000 & yes & 0 & 1720 \\
\hline Haduf E & 1300 & yes & 0 & 1420 \\
\hline Haduf W & 250 & yes & 0 & 2470 \\
\hline Jiltah & 1000 & yes & 394 & 1720 \\
\hline Raast al-Milh & 1375 & yes & 0 & 1345 \\
\hline Rajmi & 1200 & yes & 0 & 1520 \\
\hline Rusays & 1000 & yes & 0 & 1720 \\
\hline Rusays S & 1200 & yes & 355 & 1520 \\
\hline Saruj & 500 & no & 644 & 1470 \\
\hline Shiyya & 500 & yes & 0 & 2220 \\
\hline \multicolumn{5}{|c|}{ Epidosites at stratigraphic level of Sheeted Dike Complex } \\
\hline Falah $^{2}$ & n.d. & n.d. & n.d. & n.d. \\
\hline Fazah & 1200 & yes & 2594 & 3770 \\
\hline Hajmiliah $^{2,3}$ & n.d. & n.d. & n.d. & n.d. \\
\hline Hawqayn & 250 & yes & 1250 & 1750 \\
\hline Rajmi $\mathrm{W}^{4}$ & $0-950$ & yes & 1030 & 3670 \\
\hline Salahi & 925 & no & 1705 & 2895 \\
\hline Wadi Andam ${ }^{2,3}$ & n.d. & n.d. & n.d. & n.d. \\
\hline
\end{tabular}

${ }^{1}$ Calculated by accounting for regional dip of volcanic sequence

${ }^{2}$ No outcrop of the SDC/Geotimes boundary

${ }^{3}$ Approximate locations from Juteau et al. (2000)

${ }^{4}$ Epidosite extends from base of Sheeted Dike Complex into lowermost Geotimes lavas

${ }^{5}$ Based on the following thickness ranges for volcanic units: Geotimes: $1000 \mathrm{~m}$; Lasail: 250-750 m; Alley: 480-970 m, which includes Boninitic Alley: 150-300 m (Alabaster et al., 1982; Kusano 2014; Gilgen et al. (2014) 
Gilgen et al. "Timing and Depth of epidotization"

\section{Table 4}

Distance from individual epidosite alteration zones to nearest outcropping intrusive body

\begin{tabular}{|c|c|c|c|c|c|c|}
\hline \multirow[t]{2}{*}{ Epidosite } & \multicolumn{2}{|c|}{ Coordinates [UTM 40N] } & \multirow{2}{*}{$\begin{array}{l}\text { Type of } \\
\text { intrusion }^{1}\end{array}$} & \multirow{2}{*}{$\begin{array}{l}\text { Distance } \\
\text { (m) }\end{array}$} & \multirow[t]{2}{*}{ Bearing } & \multirow{2}{*}{$\begin{array}{l}\text { Intrusion stratigraphically } \\
\text { underlies epidosite? }\end{array}$} \\
\hline & East & North & & & & \\
\hline \multicolumn{7}{|c|}{ Epidosites at stratigraphic level of extrusive rocks } \\
\hline \multirow[t]{2}{*}{ Ajeeb } & 432000 & 2739800 & $\mathrm{~T}^{\prime}$ & 900 & $S$ & No \\
\hline & & & $\mathrm{T}^{\prime} / \mathrm{G}^{\prime}$ & 5200 & WNW & Yes, but large fault zone in between \\
\hline Bani Umar N & 438000 & 2703800 & $\mathrm{~T}^{\prime} / \mathrm{G}^{\prime}$ & - & - & Epidosite alters intrusion \\
\hline Bani Umar S & 438900 & 2700300 & $\mathrm{~T}^{\prime} / \mathrm{G}^{\prime}$ & 3600 & NNW & No \\
\hline Haduf E & 431600 & 2742000 & $\mathrm{~T}^{\prime}$ & 765 & WNW & Partially \\
\hline Haduf W & 430600 & 2741800 & $\mathrm{~T}^{\prime}$ & 400 & NNW & No \\
\hline Jiltah & 430500 & 2744200 & $\mathrm{~T}^{\prime}$ & - & - & Epidosite alters intrusion \\
\hline Raast al-Milh & 437000 & 2730800 & $\mathrm{~T}^{\prime} / \mathrm{G}^{\prime}$ & 2040 & W & Yes, but fault zone in between \\
\hline \multirow[t]{2}{*}{ Rajmi } & 435500 & 2726000 & HT & 2900 & SSW & No \\
\hline & & & Small G' & 1340 & $S$ & No \\
\hline Rusays & 444400 & 2716400 & Very small T' & 4380 & SW & Yes \\
\hline Rusays South & 445100 & 2713600 & Very small $\mathrm{T}^{\prime}$ & 3000 & $\mathrm{~W}$ & No \\
\hline Saruj & 438800 & 2695250 & $\mathrm{~T}^{\prime}$ & - & - & Epidosite alters intrusion \\
\hline Shiyya & 443600 & 2715000 & Very small $\mathrm{T}^{\prime}$ & 2800 & SW & Yes \\
\hline \multicolumn{7}{|c|}{ Epidosites at stratigraphic level of Sheeted Dike Complex } \\
\hline Falah & 543500 & 2602900 & HT & - & - & Within intrusion \\
\hline Fazah & 443100 & 2710800 & $\mathrm{G}^{\prime}$ & - & - & Epidosite alters intrusion \\
\hline Hajmiliah $^{2}$ & 536600 & 2607200 & HT & - & - & Within intrusion \\
\hline Hawqayn & 539100 & 2609100 & HG/HT & 2500 & SW & Yes \\
\hline Rajmi W & 433200 & 2723800 & HT & 850 & SE & No \\
\hline Salahi & 448400 & 2671900 & $\mathrm{HG} / \mathrm{HT}$ & 200 & WSW & Yes \\
\hline Wadi Andam ${ }^{2}$ & 636650 & 2544100 & HG & 3000 & NW & Yes \\
\hline
\end{tabular}

${ }^{1} \mathrm{~T}^{\prime}=$ Late Tonalite; G' = Late Gabbro; HT = High-Level Tonalite; HG = High-Level Gabbro

${ }^{2}$ Approximate locations from Juteau et al. (2000) 


\section{Standard model}

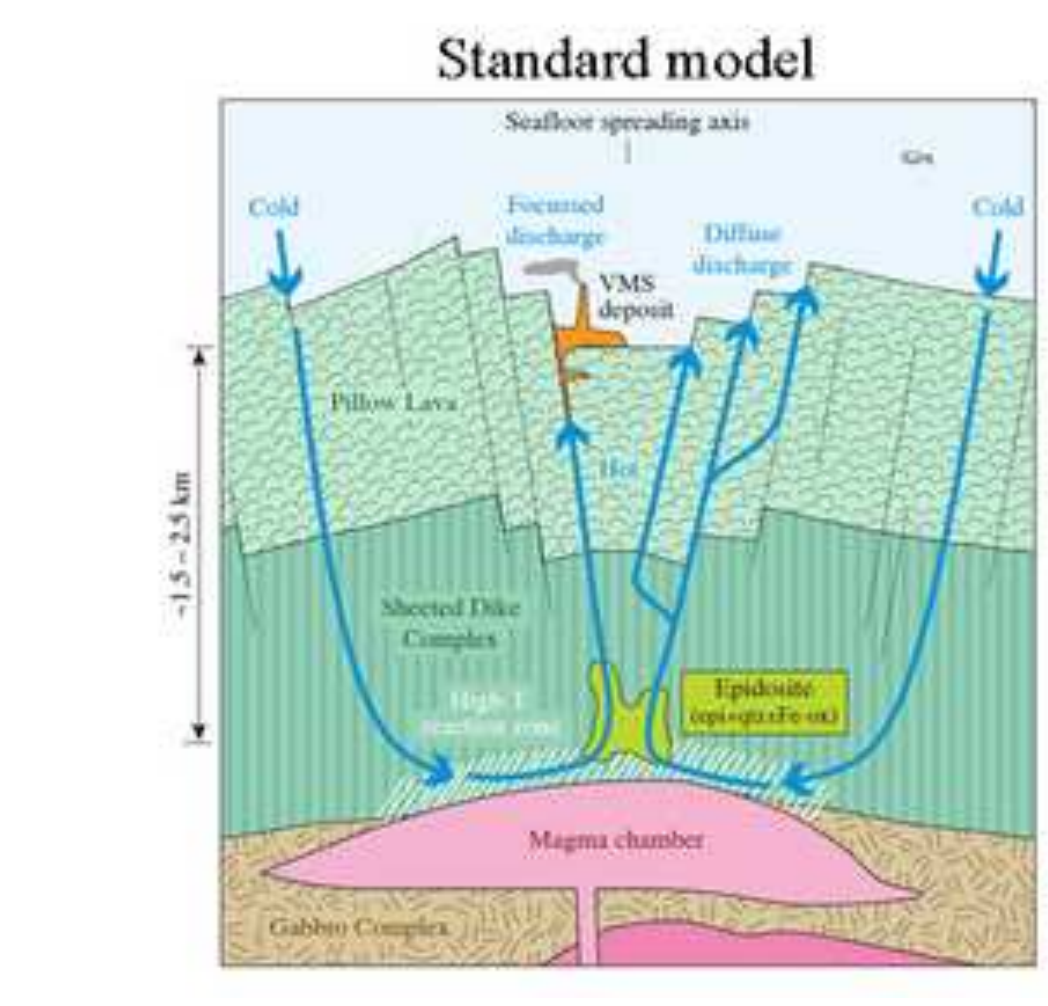

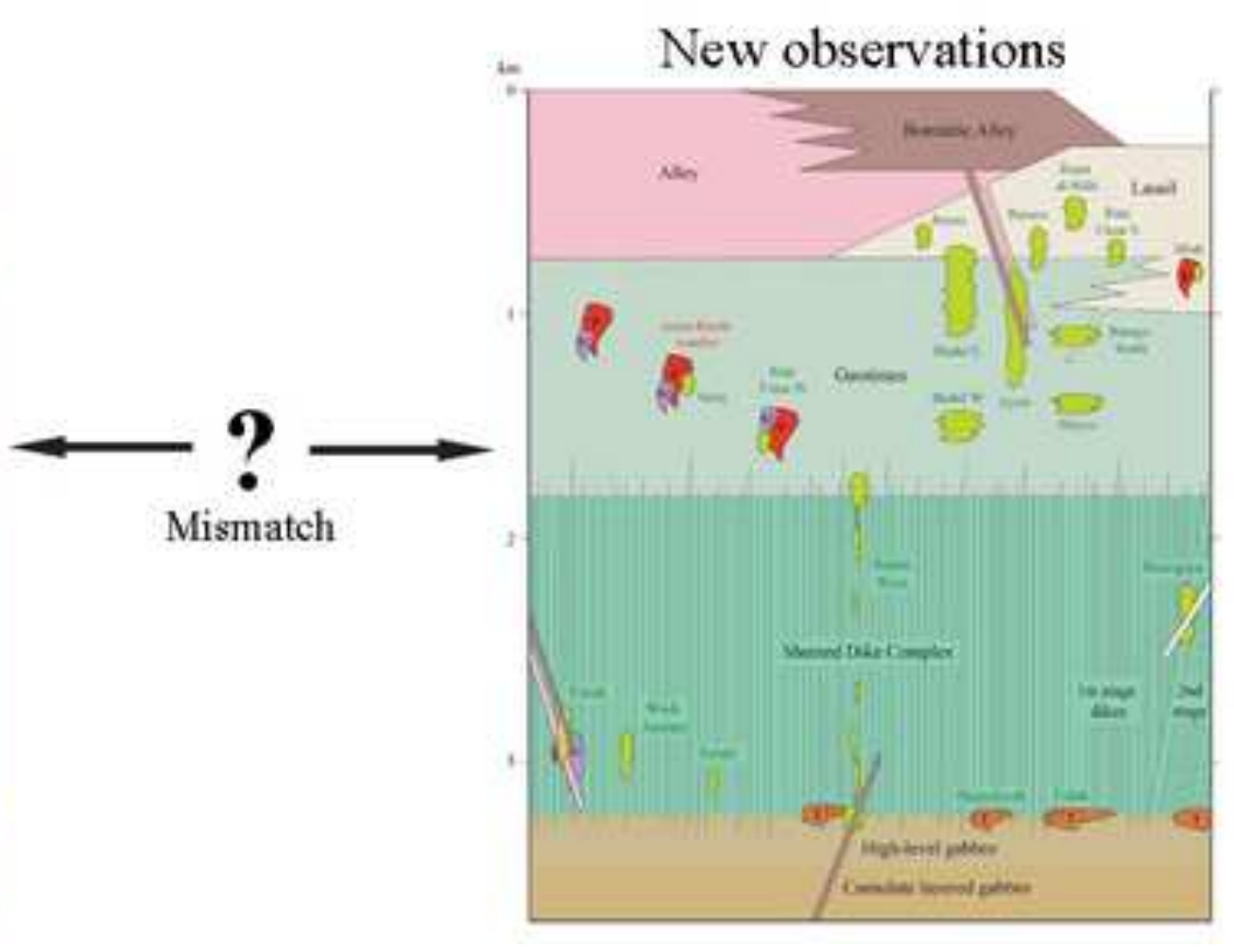

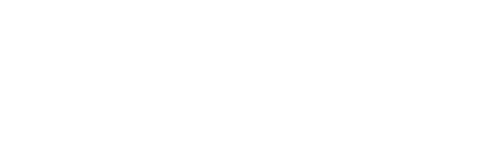

